U.S. Department of the Interior

Bureau of Land Management

BURNS DISTRICT OFFICE

HC 74-12533 Hwy 20 West

Hines, Oregon 97738

March 1999

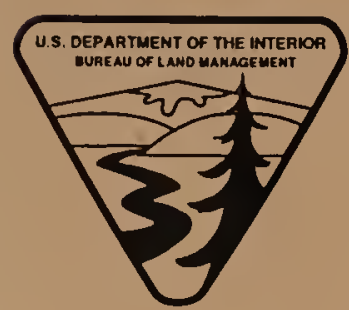

\title{
Planning Update for the Burns District
}

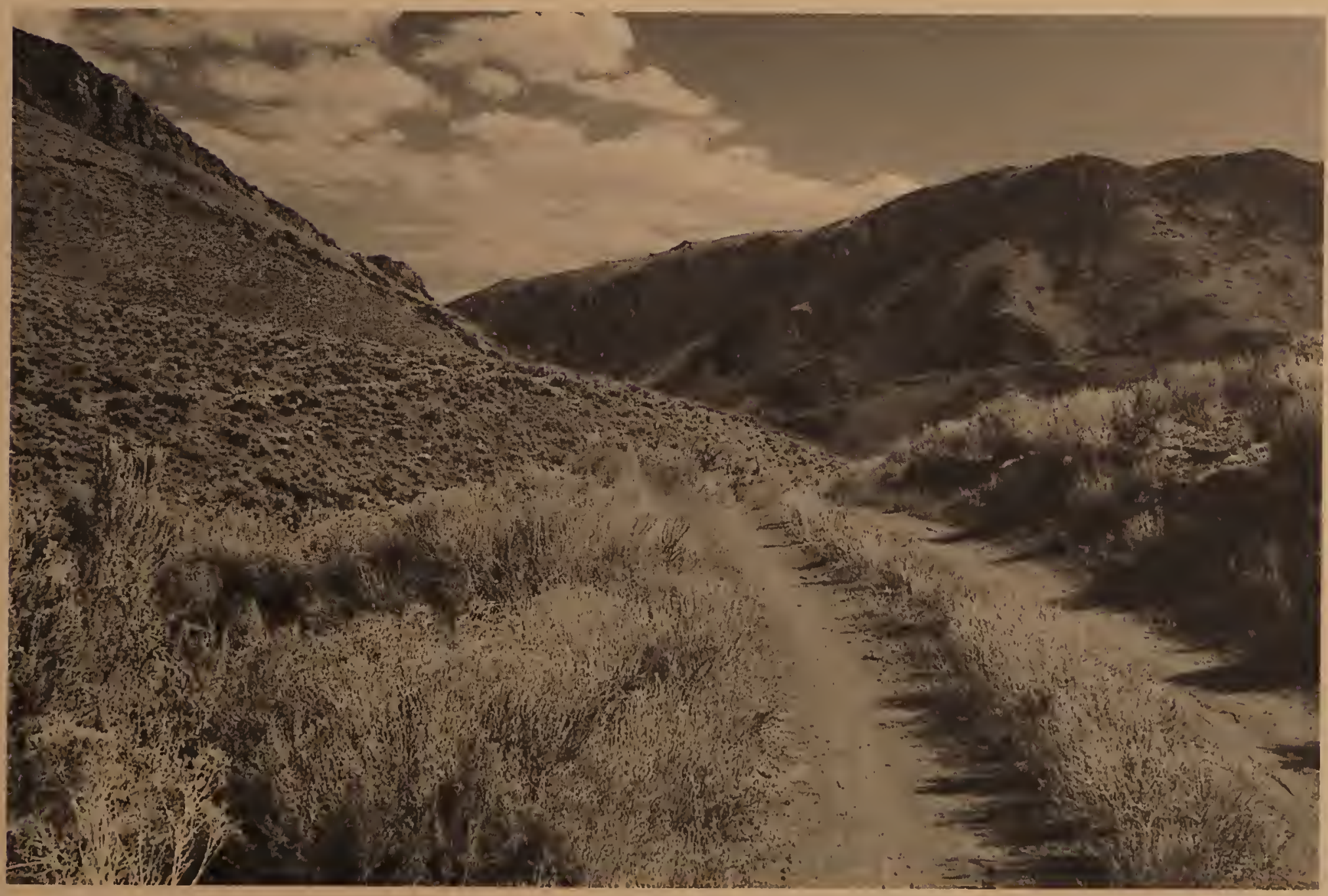

Denio Creek Area, Pueblo Mountains. 
As the Nation's principal conservation agency, the Department of the Interior has responsibility for most of our nationally owned public lands and natural resources. This includes fostering the wisest use of our land and water resources, protecting our fish and wildlife, preserving the environmental and cultural values of our national parks and historical places, and providing for the enjoyment of life through outdoor recreation. The Department assesses our energy and mineral resources and works to assure that their development is in the best interest of all our people. The Department also has a major responsibility for American Indian reservation communities and for people who live in Island Territories under U.S. administration.

\author{
BLM Library \\ enver Federal Center \\ $1 \mathrm{dg} .50, \mathrm{OC}-521$ \\ D. Box 25047 \\ Denver, CO 80225
}

BLM/OR/WA/PL-99/020+1792 


\section{U.S. DEPARTMENT OF THE INTERIOR BUREAU OF LAND MANAGEMENT}

BURNS DISTRICT OFFICE

HC 74-12533 Hwy 20 West

Hines, Oregon 97738

Web Site: http://www.or.blm.gov/Burns

\section{PLA
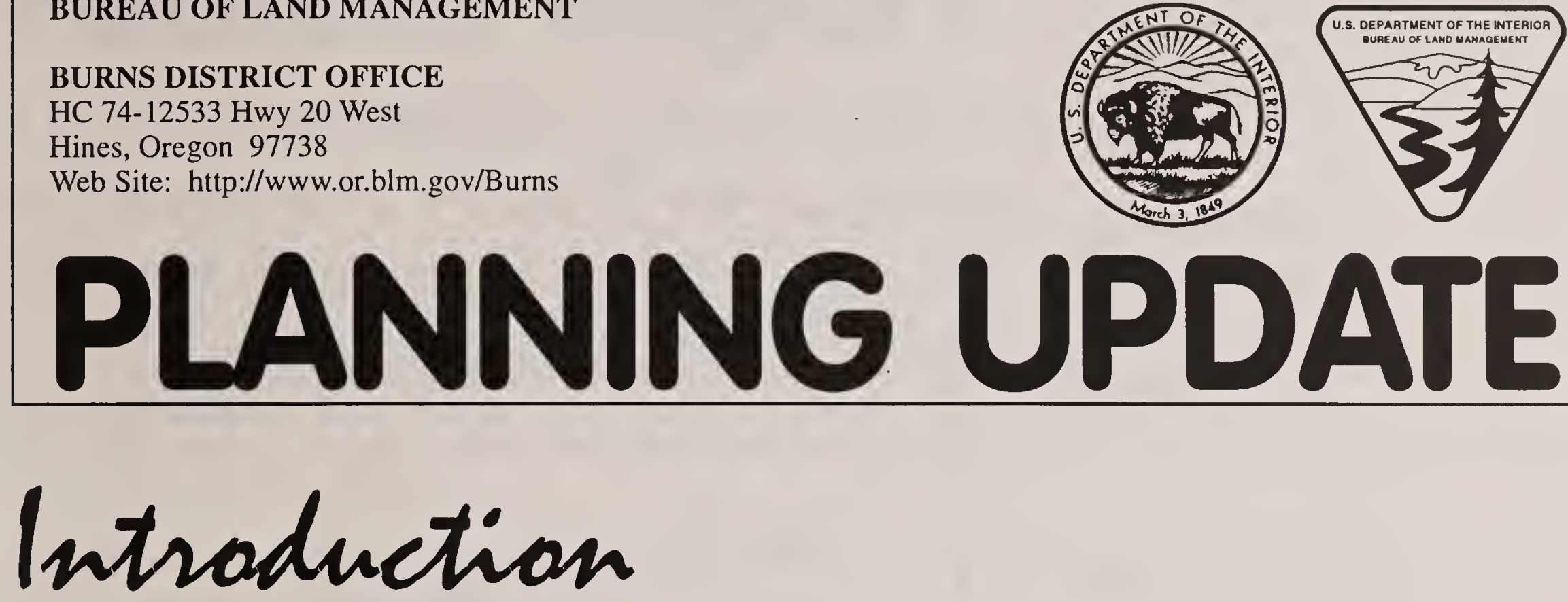

This is the eighth annual Planning Update published by the Burns District. We hope you will give us feedback on its content, layout, and usefulness to you.

It is our desire to keep you informed on issues, activities, and opportunities we think are of interest to our publics. More importantly, we are seeking ideas and comments from those who may be affected by our multiple-use management programs. For general information or comments regarding the Planning Update, please write to the address shown above.

The last Planning Update although issued September 1997, included only accomplishments for FY96 and planned work for FY97. Due to extenuating circumstances the Planning Update reporting FY97 accomplishments and planned work for FY98 were missed. Therefore, this Planning Update will report significant work for various programs for FY97-98 and planned work for FY99.

\section{What You Can find In This Document}

Updates like this one have been published annually. While a flexible format will be maintained, major sections similar to those described below will be included in each edition.

Feature Report: Reports in this section highlight high profile projects or planning efforts in the District.

Summary of Work: This section identifies the fiscal year accomplishments and work proposed for the following year. This will usually only discuss significant work or issues. More general information can be provided to individuals as requested.

Range Program Summary: This section outlines the progress being made in implementing the rangeland management objectives identified in the Resource Area's land use plans.

Environmental Assessment Register: Listed in this section are those Environmental Assessments (EAs) expected to be completed this fiscal year. Some may have been identified in the last update, but have not yet been completed. 


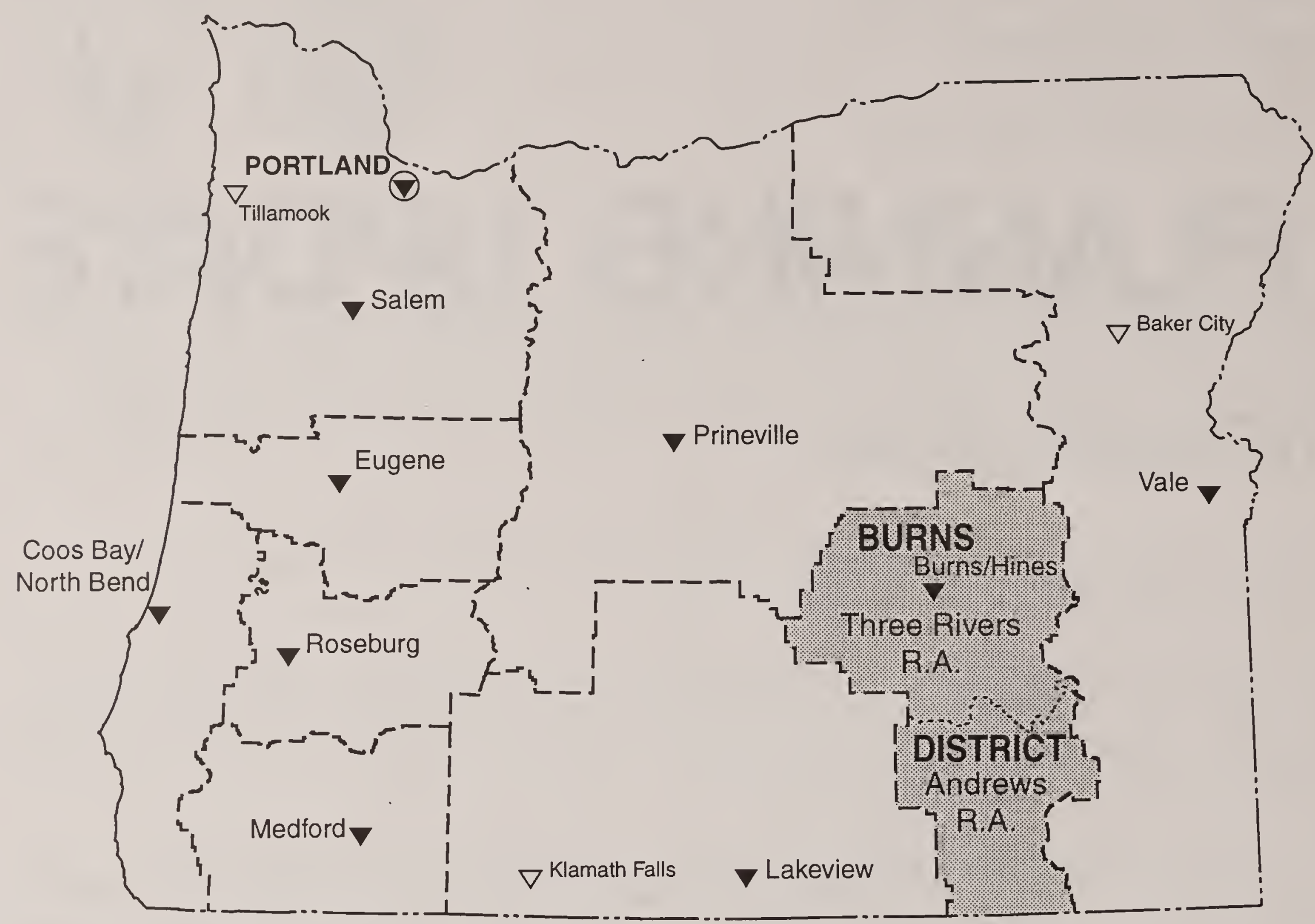

\section{LEGEND}

$\theta$ BLM State Office

$\nabla$ BLM District Office

$\nabla \quad$ BLM Resource Area Office

- - BLM District Boundary

......- BLM Resource Area Boundary

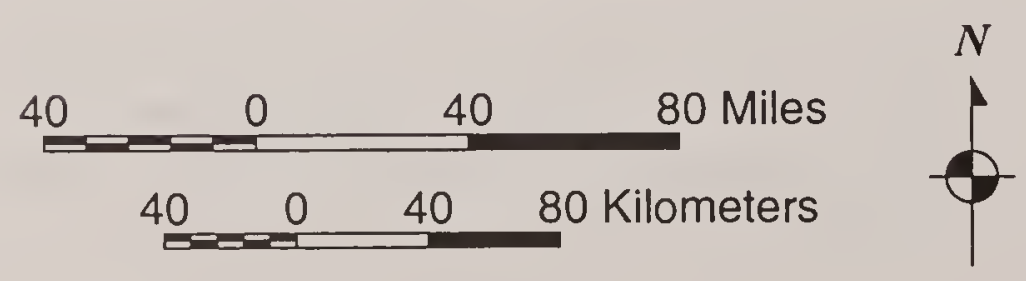

U.S. DEPARTMENT OF THE INTERIOR

Bureau of Land Management

\section{BURNS DISTRICT}

1999

GENERAL LOCATION 


\section{Feature Report \\ Draft Southeastern Oregon Resource Management Plan/Environmental Impact Statement}

The Draft Southeastern Oregon Resource Management Plan/Environmental Impact Statement (SEORMP/EIS) looks into options for future management of Bureau of Land Management (BLM)-administered land in the Vale and Burns Districts. Its goal is to find different combinations of resource management actions to address concerns and resolve identified conflicts.

The document identifies management criteria for the 20 -year life of the plan, and presents a range of five management alternatives which respond to issues raised during the scoping process. These alternatives offer a wide spectrum of management considerations ranging from emphasizing commodity production (Alternative $\mathrm{A}$ ) through not allowing any commodity production (Alternative E).

The Planning Area. The area included in this plan covers 4.5 million acres in Malheur County, 1.7 million acres in Harney County, and almost 10,000 acres in Grant County (not included). Management objectives and desired future conditions are proposed and analyzed only for BLM-administered land.

Desired Range Future Condition. The document identifies desired range future conditions for the planning area.

Adaptive Management. In striving to meet the desired range future conditions, management actions will follow the adaptive management process. Adaptive management is an ongojng process that provides managers the opportunity to evaluate how well management is meeting objectives. Managers can then utilize additional strategies to arrive at identified future conditions.

What the Plan Covers. Issues developed with public input during the scoping process and considered in this document include:

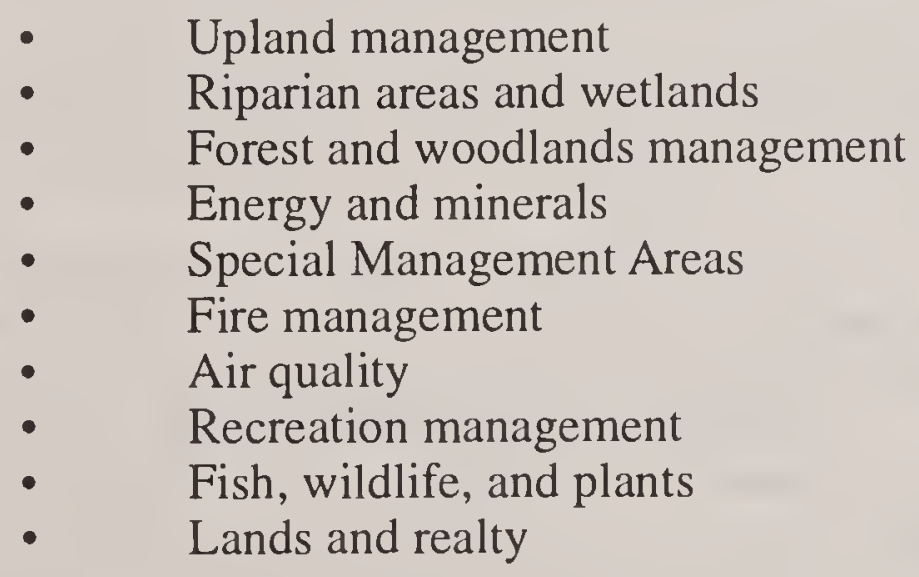

The Draft SEORMP/EIS was available and open for comment until March 1, 1999. Copies are located at public libraries in Burns, Ontario, and Vale and BLM Burns and Vale Offices. The document is also posted on the internet at http://www.or.blm.gov/Vale or http://www.or.blm.gov/Burns. If you would like to receive a printed copy or CD version, please contact Gary Cooper at (541) 473-3144 or Glenn Patterson at (541) 573-4400.

After analysis of comments, a Final SEORMP/EIS is expected to be released by June/July 1999, and a Record of Decision by October 1999. 


\section{Wild Horse and Burro Program}

The Burns District is the lead office for Oregon and Washington's wild horse adoption program. The District has eight wild horse Herd Management Areas (HMAs) and provides support for the management of 11 others that are primarily in the Lakeview and Vale Districts. In addition, there is one herd managed by the Ochoco National Forest near Prineville and another near Dayville managed jointly by the BLM and the Malheur

National

Forest.

At any one time in Oregon there are about 2,000 wild horses that roam public land in the 21 HMAs.

The herd numbers increase annually at a rate of about 20 percent.

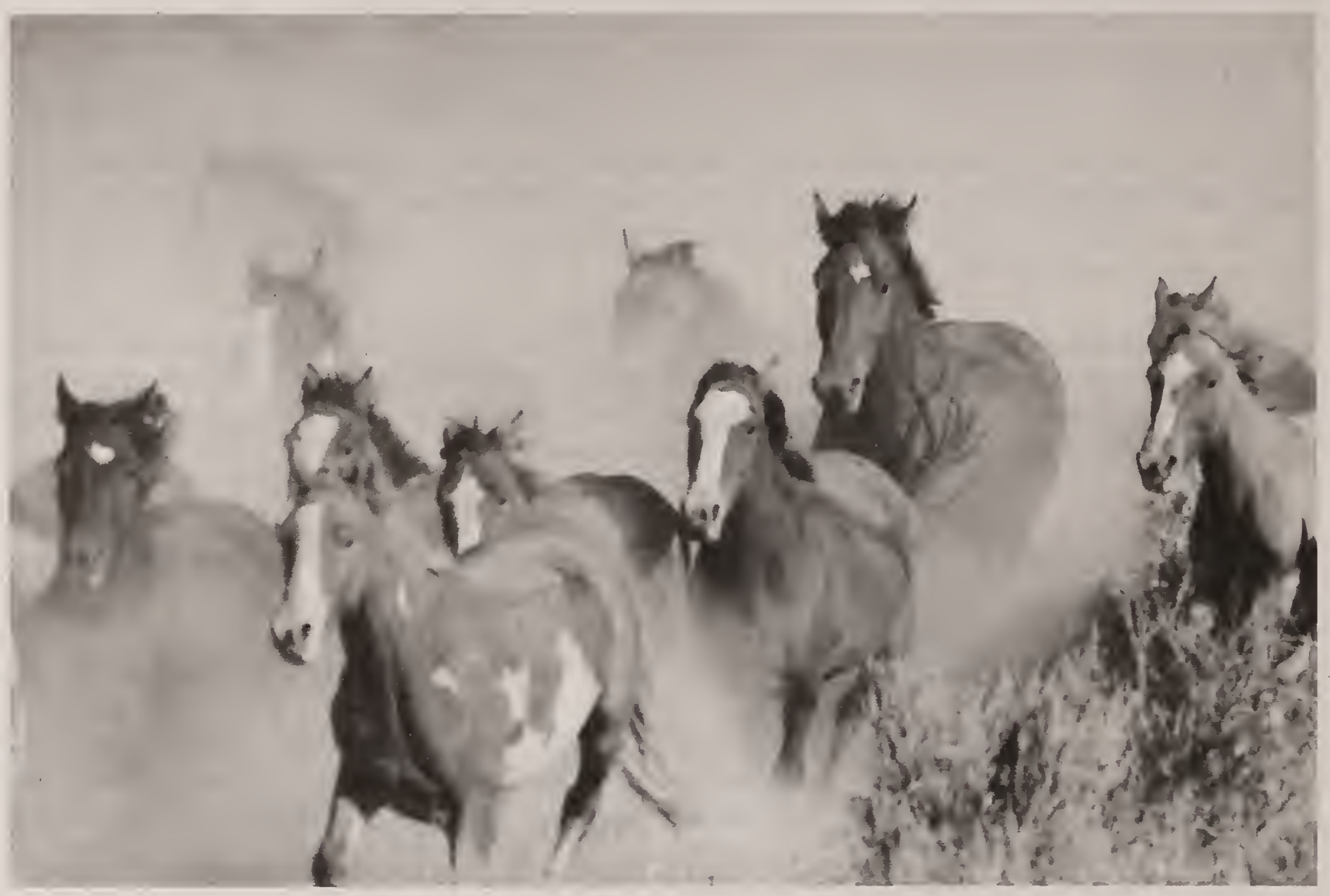

Each herd is

gathered every 3 to 5 years depending on range conditions and actual population numbers which are determined by range studies and periodic census.

Oregon's annual gathering program makes 400 animals, 5 years and younger available to the public through the Wild Horse Adoption Program. Oregon's horses are nationally known for their quality and color.

Each of Oregon's herds have their own unique characteristics. Some examples are the South Steens pintos, Hay Creek and Palomino Butte palominos, Warm Springs Appaloosas, Stinkingwater horses that have draft blood, and the highly sought after Kiger mustangs in the Kiger and Riddle HMAs.

From 1997 to present, 662 horses were gathered from the Burns District's Warm Springs, Alvord-Tule, Heath Creek-Sheepshead, South Steens, and Palomino Buttes HMAs.

Gathered animals are available to qualified adopters through adoption events held at the Burns Wild Horse Corrals and in cities throughout Oregon and Washington. Burros from the southwest are occasionally available at some Oregon adoption events. Nine adoptions were held in 1998 and seven will be held in 1999. On an annual basis approximately 400 animals are adopted to qualified applicants throughout Oregon and Washington. Adopters often come from Idaho and occasionally California to adopt Oregon horses.

Wild horse gentling demonstrations have been provided at most recent wild horse adoptions. These demonstrations provide adopters an opportunity to learn about a variety of gentling and training techniques.

In March 1997, the wild horse regulations were changed to allow a new method to set adoption fees. Competitive bidding is now used at all adoption events to establish individual adoption fees for each animal. This change was 
initiated to recover a higher proportion of the program's cost, and to allow adopters to decide what they will pay to adopt an animal. At Oregon's recent adoptions, competitive bid adoption fees ranged from $\$ 125$ to $\$ 675$ with an approximate average of $\$ 200$. The base adoption fee remains at $\$ 125$.

Remaining and Upcoming adoption events in 1999 include:

$\begin{array}{ll}\text { February } 12 \text { and } 13 & \text { Canby, Oregon } \\ \text { April } 24 & \text { Odessa, Washington } \\ \text { May } 8 \text { and } 9 & \text { Klamath Falls, Oregon } \\ \text { June } 5 \text { and } 6 & \text { Puyallup, Washington } \\ \text { September (to be announced) } & \text { Burns, Oregon }\end{array}$

Through a new pilot gentling and training program, trained geldings ranging from 6 to 10 years old will be available at some of these adoption events. These horses will be trained to lead, stand tied, and load into a trailer.

A national adoption compliance program was initiated in 1998. Adopters are selected randomly for on-the-ground checks of their facilities and adopted animals. Inspections of 180 adopters and 305 animals in Oregon and Washington found most animals well cared for and in well-maintained facilities. Corrective actions were implemented for several cases of minor neglect, and one animal was repossessed for violations of a more serious nature.

On November 29, 1997, an arson fire destroyed the barn at the Burns Wild Horse Corrals. No horses were injured as a result of the fire, but 55 horses escaped from the corral system. Although the Federal investigation of this incident continues, no arrests have been made. Costs to replace the barn, equipment lost in the fire, recapture of escaped horses, and to set up temporary chute facilities were approximately $\$ 500,000$. A reward of $\$ 30,000$ is offered for information that leads to the arrest and conviction of the arsonist(s).

Horse enthusiasts are finding that wild horses have a place among America's horses, and that they perform admirably in a variety of situations. Adopters report that the gentling process is occasionally challenging, but always rewarding. Wild horses are commonly used for pleasure and trail animals, for ranch work, and occasionally in competitive events. They are known for their intelligence, endurance, and agility.

Information about the Wild Horse Program is available through the internet at the following sites:

National Wild Horse and Burro Web Page: http://www.blm.gov/whb

Burns District Home Page: http://www.or.blm.gov/Burns/burns_wild_horse_and_burros.htm

Adoption applications and information may also be obtained by calling the Burns District Office at (541) 5734400 .

\section{Water Related Issues}

Water quality and riparian areas continue to be important issues on public land. Functioning riparian zones and good water quality help provide the foundation for healthy fish and wildlife populations. As part of a national effort on public land, all perennial streams will be assessed using the Proper Functioning Condition (PFC) assessment method. This is a BLM/Forest Service interdisciplinary method of rating riparian condition. Streams are rated by the stability and capability of their physical characteristics to safely dissipate stream energy. There are three rating levels: PFC, functioning at risk (upward or downward trend), and nonfunctioning. At a minimum, the stream must have adequate riparian vegetative diversity and correct channel dimensions in order to meet the standard of PFC. Our overall goal is to achieve advanced ecological status except where resource management objectives require an earlier successional stage. Assessing the condition of public land streams improves our understanding of stream dynamics and helps us to make better land management decisions. In 1998, the District assessed 277 miles of perennial streams. We will complete the remaining 163 miles in 1999. 
Our staff is also monitoring water quality on streams throughout the District. The District monitored 52 sites in 1997, 42 sites in 1998, and plans to monitor 50 sites in 1999. At each site we collect data on dissolved oxygen, $\mathrm{pH}$, specific conductivity, turbidity, and streamflow at least twice a year. We also collect continuous water temperature data through the warm season. Over time, this data aids in our understanding of how broad watershed management actions can influence water quality. Our goal is to work toward meeting all Oregon State water quality standards on our streams. Good water quality is a crucial part of maintaining the high biodiversity which riparian zones provide.

The District began working with the Oregon Department of Environmental Quality and the U.S. Environmental Protection Agency on drafting a nonpoint source pollution Water Quality Management Plan/Total Maximum Daily Load (WQMP/TMDL document) to address several streams under the Clean Water Act. Based on the South Steens Allotment Management Plan and the Catlow Redband Trout and Catlow Tui Chub Conservation Agreement and Strategy, this WQMP/TMDL is one of the first in the nation to address solely nonpoint source pollution, with management measures aimed at restoring the watershed conditions rather than point-source pollution control. Efforts to finalize this plan are continuing in 1999. 


\section{SUMMARY OF WORK ACCOMPLISHMENTS AND PLANS}

This section is not intended to be a comprehensive description of all activities, but rather a summary of significant activities and land use implementation actions, both accomplished and planned. Should you want more information, please contact this office.

This summary includes 1997 and 1998 accomplishments and 1999 planned work for the following programs:

Cultural Heritage Program

Fire Management

Fish/Wildlife

Lands and Realty

Minerals

Recreation

Vegetation/Forestry

Volunteer Program 


\section{CULTURAL HERITAGE PROGRAM}

Research projects at five archaeological sites were pursued by University Nevada Reno (UNR) and Washington State University. While Washington State was learning about prehistoric lifeways in the Catlow Valley, UNR was discovering an 8,600-year-old beach site near Harney Lake. The District and Burns Paiute Tribe applied for, and received, a State Historic Preservation Office grant to inventory a portion of the Biscuitroot Cultural Area of Critical Environmental Concern (ACEC). The team of tribal high school students and the tribal archaeologist found a number of sites and completed 800 acres of survey. A reexamination of paleontological localities in Three Rivers Resource Area was completed with an important site containing small mammals found and collected. Historic restoration efforts at the Gap Ranch Civilian Conservation Corp site and Riddle Brothers Ranch National Register Historic District continued and interpretive efforts began.

Proposed projects for 1999 include additional excavations near Harney Lake and in Catlow Valley by university research teams as well as paleontological survey in the Steens Mountain area. Historic restoration efforts will continue at the Gap Ranch Civilian Conservation Camp and the Riddle Brothers Ranch National Historic District.

\section{FIRE}

\section{MANAGEMENT}

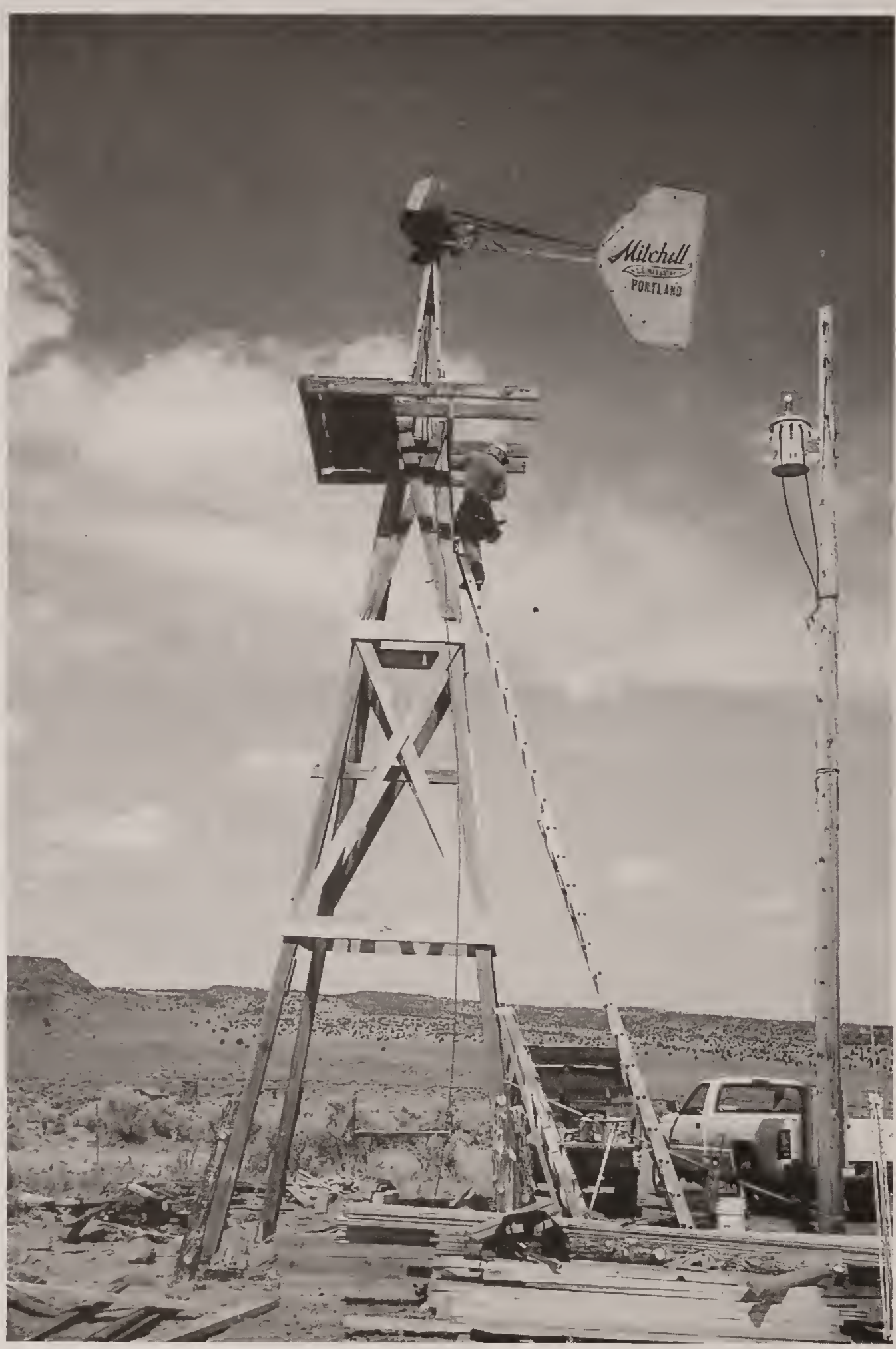

Restoring Historic Gap Ranch "CCC" Windmill.

The Burns Interagency Fire Zone (BIFZ) completed its second year as an interagency

Fire organization. This effort is a cooperative agreement with the Snow Mountain Ranger District, Ochoco National Forest; the Burns Ranger District, Malheur National Forest; and the Burns District, BLM. The Fire organization is operated as one organization, reporting to a single Fire Management Officer. As with all new organizations, there are a lot of issues to deal with in order to function properly, however, things are beginning to work efficiently.

The Burns Interagency Communications Center provided fire dispatching services for BIFZ participants as well as Malheur National Wildlife Refuge and Oregon Department of Forestry. The Center handled 87 fires; 72 fires were lightning caused for 8,216.6 acres and 15 fires were human-caused for 19,160.95 acres. Portions of the wildfires are determined to need reseeding due to a high resource value(s), i.e., critical wildlife habitat and plant diversity. This past year, the District reseeded approximately 3,700 acres. The Center also assisted the National fire fighting effort by completing 15 engine assignments and 31 overhead team assignments off District. 
The Burns BLM accomplished several prescribed fire projects including 2,663 acres on the South Steens burn; 2,650 acres on the Riddle Mountain burn; 30 acres on the Moon Hill burn; and 15 acres on the Chickahominy burn.

Continued educational, practical, and developmental experiences for our Fire staffs are keys to the continued growth and success of our organization. Broader application of prescribed fire, completion of updated Fire Management Action Plans, and collocation of fire resources will facilitate the direction of the programs through the 1999 field season. We are planning prescribed burning on two areas in the District for approximately 12,000 acres. (This is treatment acres, black acres will be less.)

\section{FISH/WILDLIFE}

The Burns District cooperated with Ducks Unlimited, Oregon Department of Fish and Wildlife (ODFW), Malheur National Wildlife Refuge, and the Oregon Waterfowl and Wetlands Association in the construction of the North Catlow and West Chain Lake Wetland developments. These developments are providing approximately 250 acres of new wetland habitat and improved upland nesting habitat for waterfowl.

A 3-year cost-share project was completed involving the inventory of small mammals and songbirds on six sites with different densities of Wyoming big sagebrush. Other inventories were conducted for bats, northern pygmy owls, spotted frogs, and sage grouse in portions of the suspected habitat in the District.

Prescribed fire was conducted during the last 2 years over approximately 11,000 acres in cooperation with the Rocky Mountain Elk Foundation to improve wildlife habitat. Burning emphasis was placed on restoring watershed values, increasing vegetative diversity, and rejuvenating aspen stands.

Juniper were cut on approximately 1,500 acres to enhance other shrub growth and to improve forage conditions. Five aspen stands were fenced to exclude livestock, deer, and elk to allow for aspen regeneration following prescribed fire and conifer removal from the stands. A cooperative effort with the Northern Great Basin Experiment Station in studies dealing with seeded bitterbrush and juniper treatment continues for the fifth year.

Sage grouse research designed to determine the use of fire areas by sage grouse is being conducted in the Steens Mountain area.

Consultation continues with the U.S. Fish and Wildlife Service (USFWS) on the impacts of livestock

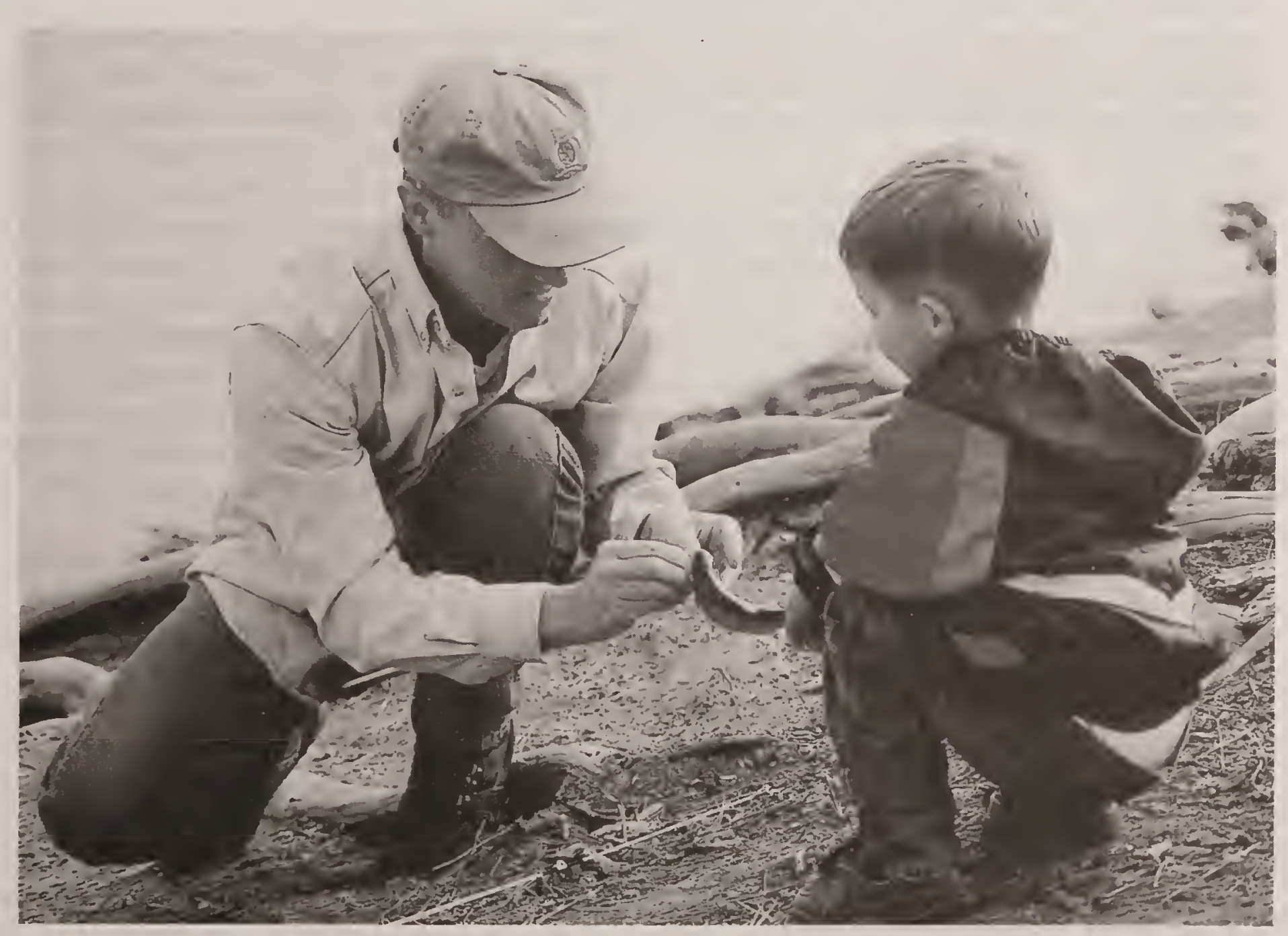

Interagency Free Fishing Day. 
grazing in Lahontan cutthroat trout habitat in the Pueblo Mountains and east side of Steens Mountain and on bull trout in the Middle Fork Malheur River. In 1999, consultation will continue, and will include the Endangered Species Act (ESA) status review for Great Basin redband trout.

The District entered into the Catlow Redband Trout and Catlow Tui Chub Conservation Agreement and Strategy with the USFWS, ODFW, Malheur National Wildlife Refuge, and Roaring Springs Ranch, Inc. Encompassing over 300,000 acres of public and private lands, the conservation agreement was developed for identifying and implementing watershed-level accelerated conservation measures for the two fish species. It was one of the first such agreements developed for a prelisting conservation effort for a vertebrate species. In 1999, in coordination with the Bring Back the Natives Program and through other cooperative agreements, work with the ranch on several identified conservation projects will continue.

Fish habitat inventories were conducted in several streams in the Burns District. Recreational fisheries projects for fish and aquatic habitat included improved recreation access and facilities at Moon Reservoir (partner Oregon National Guard), fencing projects in the Silver Creek drainage, fish transport system for fish-stocking of reservoirs (partner ODFW), and bank stabilization in Krumbo Creek. Cost-share projects for fish and aquatic habitat included elementary education with the Fields School in Pueblo Mountain streams (partner Fields School) and annual census for Borax Lake chub (partner The Nature Conservancy).

Two big game guzzlers will be constructed in areas having water deficiencies and three other guzzlers will be maintained.

Inventory for goshawks will be conducted on approximately 2,000 acres in support of the timber program.

After several years of planning, the Poison Creek Dam will be constructed in cooperation with ODFW to create a reservoir for recreational trout fishery. This dam will be located 30 miles north of Burns in the Silvies Valley and it will be 110 acre feet in size.

\section{LANDS AND REALTY}

The BLM and Harney County completed a land exchange in March 1998, which allowed for continued rural solid waste disposal. This was done by providing Harney County with long-term ownership of existing rural solid waste disposal sites previously leased to them for the same purpose. It also minimizes the United States' potential liability under various hazardous and solid waste statutes; provides for more efficient land management by both the County and BLM by disposing of isolated and unmanageable tracts of County-owned and BLM-administered lands; and consolidates Federal ownership.

The District offered for sale 1,825 acres of isolated tracts of public land identified in the land use plan for disposal. Ultimately, 1,306 acres were sold. Since the sale program started in 1996, approximately 1,800 acres have been conveyed. Resource inventories and other work were completed to prepare an additional 3,200 acres to be offered in late 1998 and 1999. Screening of disposal parcels, appraisal, and resource inventory for additional acreage will be undertaken so that the land sale program can continue into 2000 and 2001.

In June 1998, agreement was reached with the U.S. Bureau of Reclamation to return 640 acres near Warm Springs Reservoir to BLM administration and public land status. The withdrawal of approximately 2,330 acres of public land will be extended providing the Bureau of Reclamation with continued jurisdiction necessary to operate the reservoir.

A right-of-way was granted to construct, operate, maintain, and terminate a multi-state fiber optics line. The project, known as FTV Western Build, originates in Portland, Oregon, and terminates in Las Vegas, Nevada, and crosses approximately 36 miles of public land in the Three Rivers Resource Area. Construction of the project was completed in the fall of 1998. The local communications provider anticipates that fiber cable will replace existing copper in many areas of Harney County and is proposing new fiber installation in some locations. 
The EA and title work for the Davis Exchange to consolidate public and private lands on the east side of Steens Mountain is planned for this year. Once this work is accomplished and a final decision is made to proceed, the closing of the Davis Exchange would occur late this year.

Negotiations are being conducted for other exchanges on the Steens, Pueblos, and Trout Creek Mountains.

Two administrative easements and a license agreement will be secured to provide access to the Cow Creek Timber Sale. Preliminary work will be initiated for access associated with future BLM timber sales.

\section{MINERALS}

As of June 1998, there were 420 active mining claims on the Burns District. Seventy-six of the claims are for diatomite and 292 claims are for zeolites.

During December 1997, American Absorbents Natural Products opened a zeolite mine on public land east of Harney Lake and mined enough zeolite to last until summer 1999. They crushed the rock on-site and trucked it to Hines, where they are storing and packaging it for use as kitty litter and as a soil additive on golf courses.

Twenty-six abandoned shafts and adits from abandoned mercury, uranium, and gold prospects were identified. They were inventoried for archaeological values, bats, and safety issues. This winter we will determine how to mitigate the safety concerns at each site.

\section{RECREATION}

There was a considerable amount of work completed on the District the past 2 years, including new facilities, maintenance, and improvement of old facilities. Campgrounds were improved by installing solar powered water systems at Page Springs Campground; handicap access to Fish Lake fishing docks; a boat ramp, parking area, and toilet facility at Warm Springs Reservoir (a cooperative effort with Bureau of Reclamation, Oregon State Marine Board, and Harney County); and toilets at Chickahominy Reservoir. A day use picnic area was added to Page Spring Campground and 10 additional campsites and a well at Chickahominy. Several visitor information and interpretive signs were installed at various locations.

Back country sites on Steens Mountain were also improved by constructing water bars on a steep trail into Little Blitzen Canyon and approximately 200 campfire rings cleaned. A back country monitoring program was undertaken in four canyons. Campsites were measured, photographed, and plotted on a map. Data will continue to be collected on various human impacts including litter, fire rings, scarred trees, and social trails.

Plans are being developed for several trails, both walking and vehicle. These included walking trails into the fir grove and Wildhorse Canyon on the Steens Mountain, and out of Page Springs Campground. A vehicle route, called the High Desert Discovery Route, is a long distance network of quality and scenic recreational motorized routes for Off-Highway Vehicles (OHVs). This would provide a more primitive experience than offered by the Scenic Byway Systems. It will link discovery points of interest using existing roads.

\section{VEGETATION}

\section{Weeds}

There has been increasing emphasis and efforts in managing weed infestations. The District developed a Weed Management Plan and a Weed Prevention Schedule outlining what actions would be accomplished, when and by whom. The District was involved in orchestrating, funding, and implementing the Harney County Weed Manage- 
ment Partnership, which brought a full-time Oregon Department of Agriculture (ODA)/County Weed Supervisor to the area. The District also hired a Weed Coordinator. The District initiated and coordinated an ongoing research project evaluating plant varieties for road ROW rehabilitation. Partners in this project include Oregon Department of Transportation (ODOT) and USDA-ARS.

In 1997, approximately 226 acres were treated with herbicides, and 100 acres were treated manually. In 1998, approximately 1,858 acres were treated with herbicides, and 200 acres were treated manually. Weed treatments were accomplished by certified contract applicators, BLM staff and Oregon Youth Conservation Corps (OYCC) crews, ODA, Harney County, and ODOT staff. Plans for 1999 include chemically and manually treating approximately 3,500 acres, including county and State road ROWs. Four hundred sixty-seven new weed sites were identified through field inventories. Database software was purchased to accommodate an improved weeds database. The District has been actively involved in the Harney County Weed Board, participating in annual weed identification training, educational displays, development of a classroom weed curriculum, weed tours, and meetings. Plans for 1999 include continuation of all these activities.

\section{Special Status Plants and Research Natural Areas}

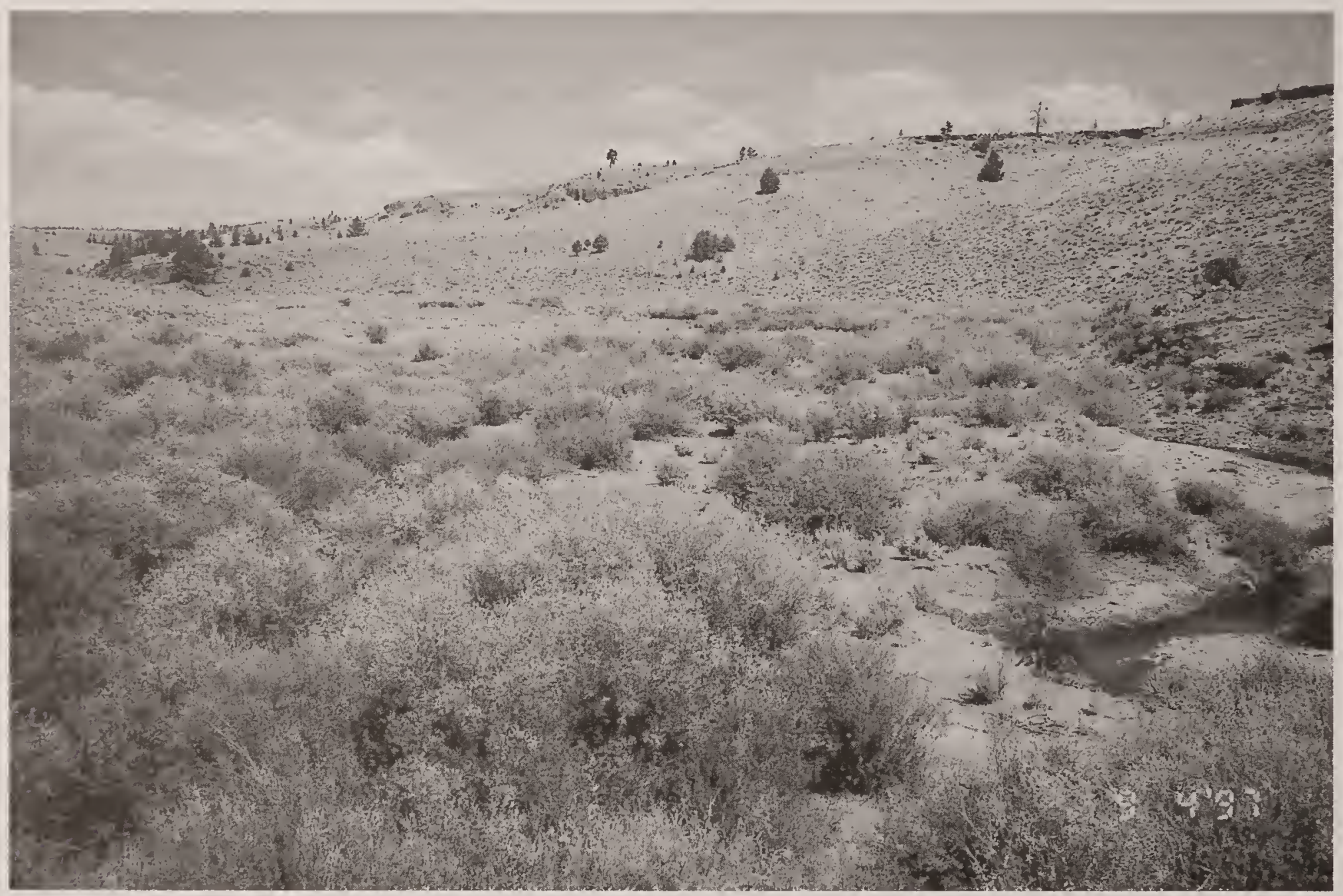

Monitoring activities continued in most of the Research Natural Areas (RNAs). With the completion of the Petersen Exchange in 1997, 1,280 acres of public land was added to the Silver Creek RNA.

A protection fence was completed to exclude the RNA addition to grazing and Silver Creek Research Natural Area. photo points were estab-

lished to document change in the riparian conditions. No Malheur Wirelettuce (Stephanomeria malheurensis) seedlings were observed in 1997, but 20 plants survived to set seed in 1998. Monitoring will continue and work on a Conservation Agreement for future management of the wirelettuce will begin in 1999. A Conservation Strategy for Columbia Cress (Rorippa columbiae) was signed. This strategy is a multiagency, multistate plan. Additional studies are continually being added. Monitoring will continue in the RNAs in 1999 and several RNAs in the Three Rivers Resource Area will be signed to identify RNA boundary and to notify the public of limited OHV designations. Weed control projects were completed in the Tum Tum Lake and Rooster Comb RNAs and will continue in 1999. 


\section{Forestry}

Seventeen acres of timber were noncommercially thinned and an aspen stand was fenced to protect aspen reproduction from grazing in the South Silvies project area. The handpiles created at a noncommercial thinning project in the Emigrant Creek Designated Old Growth stand and the Rattlesnake Eagle Roost Management Area were burned. The 78,000 board foot Cricket Salvage Sale was conducted in 1997 to recover trees killed in the Cricket Fire and 7 acres were reforested with ponderosa pine seedlings in the spring of 1998.

Forest health treatments continue to be the District's priority for forest ecosystem management. Proposed treatments include the selective harvest of about 500,000 board feet of timber, precommercial thinning of 55 acres, underburn 189 acres, and removal of invaded ponderosa pine from 13 acres of aspen followed by a fence to protect aspen reproduction from grazing. The Dry Pine precommercial thinning and aspen rehabilitation project will begin. This includes 415 acres of thinning and rehabilitation of three stands of aspen covering 20 acres. We will begin to analyze forest management options for recently acquired land in the Silvies Valley. Treatments may include selective tree harvest, noncommercial thinning, underburning, aspen rehabilitation projects, road relocations, and closures.

Special forest products, including juniper boughs, posts, and firewood will continue to be provided as a service to the public. In 1997, the Burns District combined its personal use firewood program with the Burns District, Malheur National Forest and the Snow Mountain District, Ochoco National Forest. This program enables permit holders to use one permit to cut firewood on Federal land managed by both agencies. Juniper control projects have been identified in the wildlife section of this update.

\section{VOLUNTEER PROGRAM}

During the past 2 years, volunteers donated a total of 7,080 hours of service for public land projects in the Burns District which translates to an estimated $\$ 68,000$ of savings to American taxpayers. Volunteers included groups such as the OYCC, school teachers, wilderness enthusiasts, Federal employees from outside the District, wild horse adopt-

ers, senior citizens,

Oregon

Museum of

Science and

Industry

Young

Scholars

group, and

others.

Volunteers assisted with a wide range of projects including removal of abandoned fencing, litter cleanup, repair and construction of fences around springs and

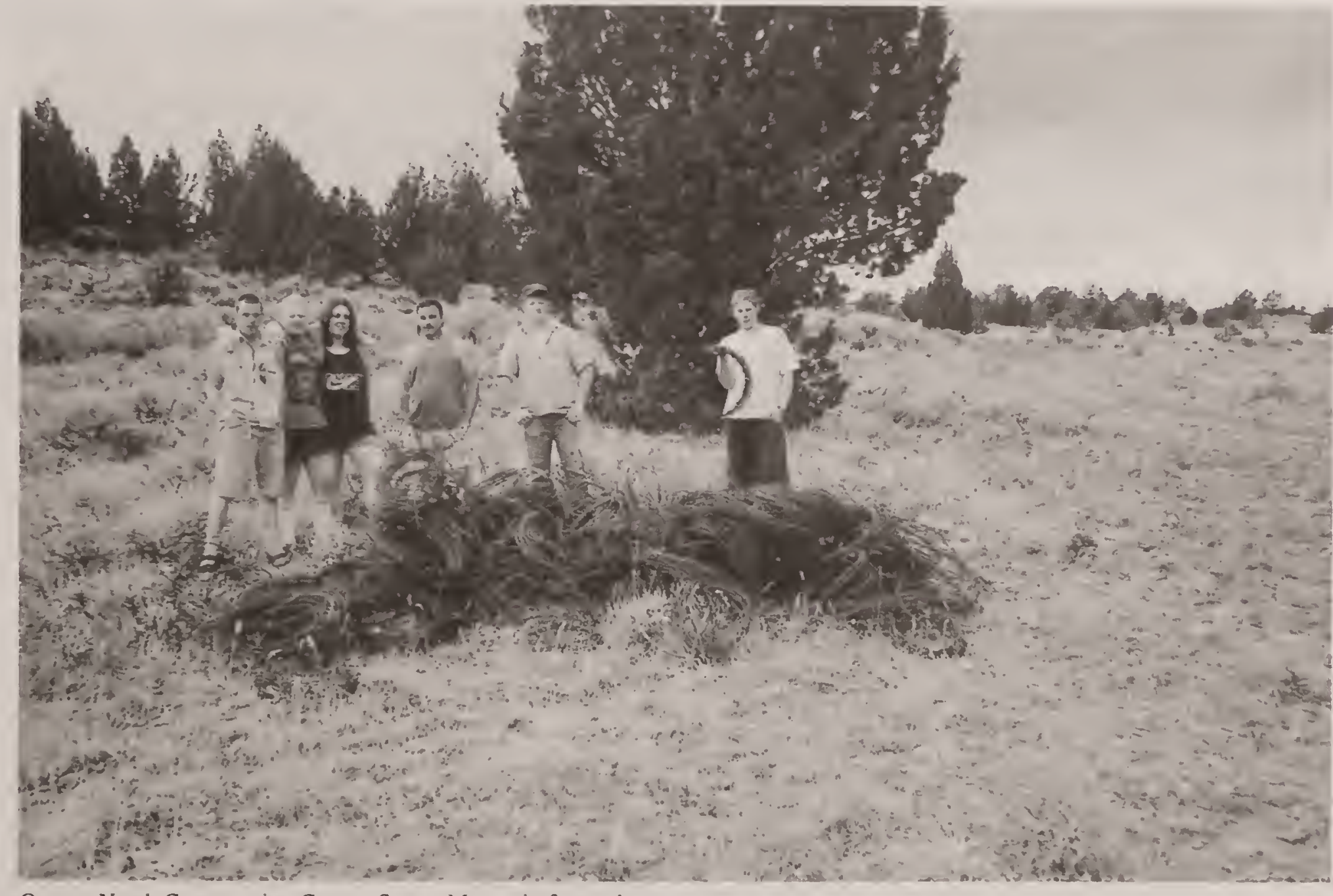

Oregon Youth Conservation Camp - Steens Mountain fence cleanup. 
riparian areas, pulling weeds, maintenance of campgrounds, construction of gap fences on wild horse ranges, built erosion control structures on abandoned trails, installed warning signs around abandoned mine shafts, and other labor intensive projects.

Other volunteers contributed many hours of archaeological survey, wildlife habitat monitoring, water quality and macroinvertebrate surveys, assisted with wild horse adoptions, inventoried noxious weeds, collected water samples, and other similar project work.

Volunteers do make an amazing contribution to management of our public land and, hopefully, benefit themselves through working in a great environment and learning some new skills.

If you or someone you know are interested in volunteering to work in the Burns District, you can contact the Burns District Volunteer Coordinator Patti Wilson at (541) 573-4400. 


\section{Burns District Rangeland Program Summary}

\section{Introduction}

The purpose of the Rangeland Program Summary (RPS) Updates for each Resource Area is to outline the progress being made in implementing the rangeland management objectives as identified in the current land use plans.

\section{Interested Publics}

Following issuance of the RPS Updates, there will be a 30-day comment period for the public to request "interested public status." If you believe that any of the future actions indicated in the RPS Updates may affect your interests, and you wish to be considered an interested public, contact the BLM Burns District Manager in writing by April 15, 1999. You must advise us of specific future actions that are of concern to you, the allotments you are interested in being involved with, and your reason for requesting this status. You will then be provided opportunities to be involved in the decision-making process for the management of livestock grazing in these allotments. If you have been an interested public in the past and have not been actively involved you will be dropped from our list. If you wish to continue your interested public status, you must advise us in writing by the above-mentioned time period.

\section{Implementing Standards and Guidelines for Rangeland Health}

In 1995, the final grazing regulations mandated each state to develop State or regional standards and guidelines for rangeland health. Statewide standards and guidelines were developed for Oregon and Washington and finalized on August 12,1997, after a process which incorporated public participation and assistance from the Resource Advisory Councils. Copies of these Standards and Guidelines were widely distributed.

In 1996, the Burns District began incorporating an assessment of the Standard and Guidelines into the allotment management evaluation process. These allotment assessments meet the requirements of the Oregon/Washington State Office Strategy for Implementing Standards and Guidelines as well as the national implementation instructions. The District continues to assess progress toward meeting the Standards and Guidelines through the evaluation process. 


\section{ANDREWS RANGELAND PROGRAM SUMMARY UPDATE}

\section{Introduction}

Priority work for the Resource Area remains those allotments with riparian/water quality values. Allotments with significant riparian resource values and updated management plans continue to show improvements in condition and trend. Management efforts specific to each allotment are listed below.

The SEORMP/EIS will reestablish resource objectives which all allotments must meet. Specific management prescriptions will still be made on an allotment or watershed basis.

\section{Grazing Permit/Lease Renewals}

Grazing permits or leases are scheduled to expire between March 1, 1999 and February 28, 2001 in the following allotments. Allotments are listed if the permit/lease for any permittee is expiring. There may be other permittees in an allotment whose permits or leases are not expiring. The required National Environmental Policy Act (NEPA) analysis will be prepared prior to renewal of these permits.

Allotment No.

6003

6008

6015

6018

6026

6028
Allotment Name

Fish Creek-Big Indian

Krumbo

Trout Creek Mountain

Tule Springs

Mann Lake

Miner's Field 


\section{FY 1997 and 1998 Accomplishments}

\begin{tabular}{|c|c|c|c|}
\hline Allotment No. & Allotment Name & Category* & Implementation Progress \\
\hline & & & $* \mathrm{I}=$ Improve $; \mathrm{M}=$ Maintain $; \mathrm{C}=$ Custodial \\
\hline 6001 & North Catlow & $\mathrm{I}$ & $\begin{array}{l}\text { A brush control project was started in January } 1998 \text { in the } \\
\text { North Duhaime Seeding Pasture, with the method of control } \\
\text { being mechanical. This maintenance project was imple- } \\
\text { mented to maintain production of the existing crested wheat- } \\
\text { grass seeding. Islands of sagebrush are being left for cover } \\
\text { for small mammals and birds. The maintenance is being } \\
\text { performed by the permittee and should be completed by } 2000 \text {. }\end{array}$ \\
\hline
\end{tabular}

The South Steens AMP is being implemented with actions outlined in the AMP/EA to accomplish resource objectives. To further augment resource objectives on private and public lands, the Catlow Redband Trout and Catlow Tui Chub Conservation Agreement and Strategy was entered into with Roaring Springs Ranch, Inc., ODFW, USFWS, and the Malheur National Wildlife Refuge in August of 1997. The upper elevation pastures were rested during 1998 and will be rested from livestock grazing during 1999 to allow recovery of prescribed burns and to accelerate establishment of deciduous woody species on portions of the riparian systems of the Catlow streams.

The Blitzen protection fence ( 8 miles) located west of the South Fork of the Donner und Blitzen, approximately on the Wild and Scenic River corridor boundary, was constructed in 1997. This fence to the Penland fence on the east boundary form the Blitzen Pasture. Public land within this pasture is closed to livestock grazing by court order because of access to the Wild and Scenic River corridor.

Livestock have been excluded from this pasture pending determination of the analysis contained in the SEORMP/EIS. This Draft EIS is currently available for public comment.

As part of the South Steens AMP, fire was reintroduced on 6,300 acres of public land through prescribed burning in the Steens and Blitzen Pastures during the fall of 1997.

As outlined in the AMP and the Herd Management Plan for South Steens HMA to maintain a thriving ecological balance and as analyzed in EA-OR-026-98-027, wild horses were gathered in October 1998. Two hundred and fifty-nine horses were captured with 91 being released back into the HMA and 168 animals removed from the area and offered for adoption.

During the summer of 1998, several wildfires within the South Steens Allotment burned 9,612 acres of public land. Of this, 3,460 acres were reseeded to plant species best adapted to the specific sites. About 18.7 miles of fencing was also constructed to protect the burned areas. Private land in the amount of 15,582 acres was also consumed by the fires. 


\section{FY 1997 and 1998 Accomplishments}

Allotment No. Allotment Name Category* Implementation Progress

*I = Improve; $\mathrm{M}=$ Maintain; $\mathrm{C}=$ Custodial

All public land burned will receive two growing seasons of rest from livestock grazing. All wildfire rehabilitation outside of WSAs was a cooperative effort between BLM and the permittee.

Road Canyon wildfire rehabilitation seeding completed in the fall of 1996, was successful with perennial grasses, forbs, and shrubs established. This area will be grazed during 1999 following the past two growing seasons of rest.

The Lauserica and Stephens Fence Extension EA OR-026-9833 has been circulated for public comment and the proposed decision issued. These fences would provide for management of the Catlow streams and accelerated improvement. These fences would create two additional pastures within the allotment. During the fall of 1999 , approximately 6,300 acres of public land within Penland and Steens Pastures will have fire reintroduced through prescribed fire. This is part of implementation of South Steens AMP/EA and Catlow Redband Trout and Catlow Tui Chub Conservation Agreement and Strategy.

The allotment evaluation scheduled for 1997 was not completed due to other workload priorities. This evaluation has not been rescheduled. The final summary judgment issued May 7, 1997, by the U.S. District Court directed BLM to analyze the impacts of livestock grazing within the Donner und Blitzen Wild and Scenic River corridor in an EIS. Further, no grazing is allowed on public land within the river corridor until this analysis is completed. Therefore, the Little Blitzen Meadows and Newton Cabin Pasture remain closed to livestock grazing pending determination based on SEORMP/ EIS. This judgment authorized BLM to construct a protection fence from the mouth of Little Blitzen Gorge to Blitzen Meadows to remove livestock access to the Little Blitzen River from Blitzen \#4 Pasture of Fish Creek-Big Indian Allotment. The BLM provided materials and the ranch constructed the fence during 1998. Six springs in the Cold Springs Pasture were maintained during FY97.

Approximately 1.75 miles on the north boundary was completed in 1997. This fence is within the Chimney Allotment and removes approximately 200 acres from the Chimney Allotment which is now within Steens Summit.

In June 1998, a flash flood destroyed six fence crossings in Bridge Creek Canyon. Plans were made to reconstruct the crossings during the 1999 field season to protect riparian habitat and fisheries. 


\section{FY 1997 and 1998 Accomplishments}

\begin{tabular}{|c|c|c|c|}
\hline Allotment No. & Allotment Name & Category* & Implementation Progress \\
\hline & & & *I = Improve; $\mathrm{M}=$ Maintain $; \mathrm{C}=$ Custodial \\
\hline 6007 & Ruby Springs & M & $\begin{array}{l}\text { One reservoir was reconstructed in December 1998. An } \\
\text { extension to an existing fence is planned for the summer of } \\
1999 \text { to improve riparian management along } 2 \text { miles of } \\
\text { McCoy Creek. }\end{array}$ \\
\hline
\end{tabular}

6008

6010

Krumbo

I

East Ridge

I

6012

Alvord

I

6014
Tum Tum

M
An allotment evaluation is currently in progress and scheduled to be completed this year.

During FY99, an EA will be written to analyze prescribed burning and juniper cutting on approximately 2,000 acres of public land in mid and lower Kiger Gorge. Natural fuel breaks, such as talus slopes, rock and limited understory in juniper communities, will be used to control prescribed burns, so acres of actual burn may vary. There are approximately 700 acres of public land with remnant aspen stands and juniper encroaching in the riparian zone and deep soil sites creating dead, dying or stressed shrub community understory. These sites would have priority for juniper control treatment.

The aspen stands within this portion of the gorge are losing or have lost species diversity. Portions of Kiger Creek have juniper filling the niche of a diverse deciduous woody community in the riparian zone.

On many portions of the areas identified for the reintroduction of fire, the loss of shrub and herbaceous plant cover with the associated root systems have accelerated erosion increasing sediment load into Kiger Creek.

All juniper cutting and reintroduction of fire would be a cooperative effort with the private landowners, ODFW, and possibly other partners.

On August 23, 1997, 2,272 acres of public land and 2,442 acres of private land burned within the north Foothills Pasture. Approximately 15 to 20 percent of the deciduous woody species along Willow Creek were burned. The rehabilitation of this fire was analyzed in EA OR-026-97-031. This resulted in 1.5 miles of temporary protection fence north of Cottonwood Creek and 1,500 acres of aerial seeding of native species. The area will have a minimum of two growing seasons of rest from livestock grazing.

An allotment evaluation and EA will be completed in 1999 to determine whether or not the allotment can support an increase in the permitted use of from 360 to 478 AUMs. The allotment is grazed during the winter and actual use and utilization studies have shown that additional AUMs are available and could be utilized. This EA will also analyze the effects of adding 1-mile of fence on the west side of the allotment to divide the allotment into three pastures. 


\section{FY 1997 and 1998 Accomplishments}

Allotment No. Allotment Name Category* Implementation Progress

6015

Trout Creek

Mountain

6020

Pueblo-Lone

Mountain
Hammond

I

6034
West Slope
*I = Improve; $\mathrm{M}=$ Maintain $; \mathrm{C}=$ Custodial

Management under the current AMP has resulted in an upward trend in riparian areas. Cool, wet conditions in the spring of 1998 caused grazing to be deferred to later than scheduled dates in the higher elevation pastures. A September 15,1998 , tour with interested publics resulted in favorable comments on the allotment condition and trend.

A 30-foot bottomless trough is being installed in the West Buckskin Pasture to replace old existing troughs and increase water capacity in the event of a pipeline failure during the pasture season-of-use.

In the fall of 1997, three drift fences were constructed on eastside drainages to help prevent early season livestock use on higher elevation meadows. Cool, wet conditions in the spring of 1998, in conjunction with the new drift fences, resulted in virtual nonuse of high elevation meadows. A September 16, 1998, tour with interested publics resulted in favorable comments on the allotment condition and trend.

In the fall of 1997, a fence was completed to create the Starr Winter Pasture. Season of use for the pasture is November 1 to February 28. Use in the pasture will offset AUMs previously utilized in the Pueblo Ridge Pasture during the spring.

A well was drilled in Long Draw in 1998, to facilitate winter grazing use in the Oregon End Winter Pasture. Two aluminum troughs were placed to ensure adequate watering capacity.

PFC assessments were completed on all eastside streams. These assessments will aid in future riparian management and achievement of riparian objectives. The upper reaches of most streams were found to be in PFC. Most lower reaches were found to be functional at-risk with an upward trend. Current early season grazing on these streams should continue to result in improvement of riparian condition.

Preliminary negotiations are being conducted on a land trade with the permittee that would reduce the amount of public land in this allotment by approximately 4,000 acres.

A 1-1/2 mile allotment boundary fence is planned for construction in summer 1999 to improve riparian management along approximately 10 miles of McCoy Creek and its tributaries. 


\title{
FY 1997 and 1998 Accomplishments
}

\author{
Allotment No. Allotment Name Category* Implementation Progress
}

$* \mathrm{I}=$ Improve $; \mathrm{M}=$ Maintain $; \mathrm{C}=$ Custodial

6040

Stonehouse

This allotment will have an evaluation completed during FY99. The results of the evaluation will form the basis for the Stonehouse AMP/EA which is scheduled to be available for public comment during FY99. The concerns which will be addressed in this evaluation and subsequent EA are riparian condition of upper Riddle Creek, Stonehouse Creek, fisheries, WSAs, upland rangeland conditions, sage grouse habitat, management of mountain meadows, juniper encroachment, and the reintroduction of fire. 


\section{THREE RIVERS RANGELAND PROGRAM SUMMARY UPDATE}

\section{Fiscal Year 1999 Plans}

During FY99, the monitoring data will be analyzed, interpreted, and evaluated to document the progress of management to meet resource objectives for the following allotments:

5205 - Venator, 5212 - Mahon Ranch, 5302 - Big Bird, 5501 - East Cow Creek, 5514 - Coal Mine Creek, 5521 Rocky Basin, 5529 - House Butte, 7002 - West Warm Springs, 7006 - Rimrock Lake, 7024 - East Sagehen.

Allotment Management Plans (AMPs) will be developed or revised for the following allotments:

4143 - Silvies, 5105 - Camp Harney, 5205 - Venator, 5212 - Mahon Ranch, 5214 - Hamilton, 5300 - Alkali, 5302 Big Bird, 5501 - East Cow Creek, 5504 - State Field, 5511 - Moffet Table, 5514 - Coal Mine Creek, 5515 - Mule Creek, 5517 - Otis Mountain, 5521 - Rocky Basin, 5524 - Dawson Butte, 5529 - House Butte, 5537 - Buck Mountain, 7002 - West Warm Springs, 7006 - Rimrock Lake, 7030 - Skull Creek.

\section{Allotment Prioritization}

When the RMP was completed in 1992, the grazing allotments were prioritized in order to focus our workload on areas with the highest resource conflicts and concerns. After 6 years, the Resource Area has progressed in resolving conflicts and concerns to the point where the biggest conflicts are not necessarily in the allotments which are ranked as the highest priority. The Resource Area is planning to reprioritize the allotments to again focus our attention on areas with the greatest concerns. As in the past, prioritization will be made on the basis of the criteria listed on Page 2-33 of the RMP. Those criteria are: wildlife habitat, riparian and wetlands, fisheries, recreation, Wilderness Study Areas, Wild and Scenic Rivers, water quality and watersheds, wild horses and burros, listed threatened or endangered species, Special Status species, and ACECs. In addition, we will be considering noxious weeds, and whether or not management is in place to resolve conflicts and concerns.

\section{Grazing Permit/Lease Renewals}

Grazing permits or leases are scheduled to expire between March 1, 1999 and February 28, 2001 in the following allotments. Allotments are listed if the permit/lease for any permittee is expiring. There may be other permittees in an allotment whose permits or leases are not expiring. The required NEPA analysis will be prepared prior to renewal of these permits. 


\begin{tabular}{|c|c|}
\hline Allotment No. & Allotment Name \\
\hline 4096 & Hi Desert \\
\hline 5105 & Camp Harney \\
\hline 5204 & Slocum Field \\
\hline 5316 & Virginia Valley \\
\hline 5325 & Marshall Diamond FFR \\
\hline 5501 & East Cow Creek \\
\hline 5502 & Rock Creek \\
\hline 5504 & State Field \\
\hline 5506 & Muddy Creek \\
\hline 5509 & Williams' Dripp Springs \\
\hline 5511 & Moffet Table \\
\hline 5524 & Dawson Butte \\
\hline 5529 & House Butte \\
\hline 5530 & River \\
\hline 5531 & Stinkingwater \\
\hline 5532 & Mountain \\
\hline 5542 & Marshall FFR \\
\hline 5551 & Lillard's FFR \\
\hline 5562 & Williams' FFR \\
\hline 5565 & Upton Mountain \\
\hline Allotment No. & Allotment Name \\
\hline 5566 & Texaco Basin \\
\hline 5567 & Miler FFR \\
\hline 5569 & Floyd's FFR \\
\hline 7001 & East Warm Springs \\
\hline 7016 & Juniper Ridge \\
\hline 7018 & Silver Lake \\
\hline 7024 & East Sagehen \\
\hline 7029 & Spring Creek \\
\hline 7030 & Skull Creek \\
\hline 7035 & Silvies Meadows \\
\hline 7037 & Coal Pit Springs \\
\hline 7039 & Cave Gulch \\
\hline 7040 & Landing Creek \\
\hline 7041 & East Silvies \\
\hline 7042 & Dole Smith \\
\hline 7043 & Lone Pine \\
\hline 7053 & Silvies Canyon \\
\hline 7057 & Wright's Point \\
\hline 7058 & Narrows \\
\hline 7063 & Round Top Butte \\
\hline
\end{tabular}

\section{Drewsey Reallocation}

In the winter of 1998, the Resource Area decided to address the issue of how to manage the unallocated forage that is being produced in the crested wheatgrass seedings south of the Malheur National Wildlife Refuge Headquarters in an area commonly known as the Diamond Seedings.

These seedings were established beginning in the late 1970's for the purpose of enabling the Bureau to move livestock off sensitive or overstocked areas while those areas were rehabilitated, seeded, or had management facilities such as fences constructed to establish grazing systems. In the early 1980's this "extra" forage was used 
for a county-run flood relief program to assist livestock operators whose private land was flooded when the levels of Malheur and Harney Lakes rose. Since then, the forage has been used for various reasons including relieving areas with too many wild horses, temporary nonrenewable forage for permittees in the seeding allotments, rest for areas before and after prescribed fires, and rest following wildfires.

One of the original objectives for maximizing forage production in the Diamond Seeding area was to establish enough forage to enable the Bureau to move permittees from other areas in the Resource Area, primarily the Drewsey and Harney area, where the allotments did not produce enough forage to meet the demand of the grazing permits. It was originally thought that the Diamond Seedings would be able to meet this demand. Over the years, all or part of several grazing permits have been moved to the seeding allotments on a permanent basis.

After grazing management evaluations were completed, it was calculated that there are approximately 3,100 Animal Unit Months (AUMs) of permanently available forage in the Diamond Seedings in the Dry Lake and Crow's Nest Allotments. The amount of grazing permit demand that is not currently being met (suspended) is almost 15,000 AUMs. Clearly, very little of the demand could be met, so the Bureau attempted to find out the most equitable method of distributing this forage. After consulting with permittees, the Harney County Court, interested publics, and the Harney County Stockgrowers Association, it was determined that the best use for the excess forage was to not allocate it to anyone. Instead, the forage will be kept in reserve to be used as relief for other areas as needed. In addition, the unallocated forage in the Double ' $O$ ' Allotment (\#7056) will also be kept in reserve. The primary uses will be for riparian improvement, rest following wildfire, and rest before and after prescribed fire. For administrative purposes, the pastures in the Dry Lake Allotment which have the excess forage will be split from the Dry Lake Allotment (\#5305) and named the Alkali Allotment (\#5300).

\section{Updated Allotment Acreages}

At the time the RMP was published, the allotment acreages listed in Appendix 9: Allotment Management Summaries, were based on the best information we had on allotment size. Very often there were different acreages listed for an allotment depending on which document you looked at. Since that time, the Bureau has digitized the allotment boundaries into a Geographic Information System. In order to have consistency and keep the RMP upto-date, the digitized acreages will be considered the correct ones. These corrected acreages may be obtained at the Burns District Office. 


\title{
FY 1997 and 1998 Accomplishments
}

\author{
Allotment No. Allotment Name Category* Implementation Progress \\ *I = Improve; $\mathrm{M}=$ Maintain $; \mathrm{C}=$ Custodial
}

4143

Silvies

An allotment management evaluation was conducted in 1998 to analyze, interpret, and evaluate whether or not present management is meeting resource objectives. A land exchange was completed in this allotment in 1997 in which approximately 5,000 acres of formerly private land came under Federal ownership. This block contains significant riparian and wet meadow resources. The evaluation was conducted on this land as well as the remaining Federal land in the allotment. There was insufficient data to calculate carrying capacity, but estimates indicate that the size of the grazing lease appears to be in excess of forage production. The objectives for big game and livestock forage have been met due to large amounts of nonuse by the permittee. The objectives for water quality, Special Status species, wetlands habitat and riparian habitat have not been met. The assessment of Standards for Rangeland Health found standards for upland watershed function and ecological processes were achieved and the standards for riparian/wetland watershed function, water quality, and Special Status species were not achieved. The evaluation recommends establishing a grazing system and rewriting the objectives to reflect the conflicts and concerns identified in the Three Rivers RMP. Additionally, the evaluation recommends a stocking rate reduction.

In order to be able to implement a grazing system, 8 miles of allotment boundary fence were built in 1998. Much of this fence was along the BLM/Forest Service boundary and is on the legal boundary of the allotment. In addition, 2.5 miles of fence were repaired and 3.6 miles of fence which was in total disrepair was removed.

An allotment management evaluation was conducted in 1998 to analyze, interpret, and evaluate whether or not present management is meeting resource objectives. Results indicate that forage demand and forage production are in balance and the current management is meeting all objectives. The assessment of Standards for Rangelands Health found that the standards for upland function, ecological processes, and Special Status species are being achieved and the standards for riparian function and water quality are not present. The evaluation recommends rewriting the objectives to reflect the resource conflicts and concerns identified in the Three Rivers RMP.

One and a half miles of fence were constructed which moves the South Fork of the Malheur River out of the Stockade Allotment (\#5206) and into a riparian pasture in this allotment. 


\section{FY 1997 and 1998 Accomplishments}

Allotment No. Allotment Name Category* Implementation Progress

$5303 \quad$ Dry Lake M

$* \mathrm{I}=$ Improve $; \mathrm{M}=$ Maintain $; \mathrm{C}=$ Custodial

5310 Riddle Mountain I

An allotment management evaluation was conducted in 1998 to analyze, interpret, and evaluate whether or not present management is meeting resource objectives. The evaluation dealt with both this allotment and the Riddle/Coyote Allotment since they are used together. Results indicate that the current management is meeting the objectives for range condition and riparian areas, but the big game habitat objective is not being met due to increased juniper density. The assessment of Standards for Rangeland Health found that the standards for upland watershed function, riparian watershed function, and ecological processes were achieved and the standards for water quality and Special Status species were not achieved. The evaluation recommends continuing the existing grazing system and rewriting the objectives to reflect the conflicts and concerns in the Three Rivers RMP. The evaluation also recommends a voluntary reduction in stocking level to rest areas prior to prescribed burning projects recommended for juniper reduction.

In September 1998, 2,200 acres of mountain big sagebrush with high levels of western juniper encroachment were burned to reduce junipers and increase forbs, grasses, and shrubs.

One-quarter of a mile of fence was built in a rimrock gap along the allotment boundary to prevent wild horses from leaving the herd area and going on to private land.

An allotment management evaluation was conducted in 1998 to analyze, interpret, and evaluate whether or not present management is meeting resource objectives. The evaluation dealt with both this allotment and the Riddle Mountain Allotment (\#5310). See Riddle Mountain Allotment for the results of the evaluation. 


\section{FY 1997 and 1998 Accomplishments}

\begin{tabular}{|c|c|c|c|}
\hline Allotment No. & Allotment Name & Category* & Implementation Progress \\
\hline & & & $* \mathrm{I}=$ Improve $; \mathrm{M}=$ Maintain $; \mathrm{C}=$ Custodial \\
\hline 5502 & Rock Creek & M & $\begin{array}{l}\text { An allotment management evaluation was conducted in } 1997 \\
\text { to analyze, interpret, and evaluate whether or not present } \\
\text { management is meeting resource objectives. The results } \\
\text { indicate that the current grazing system has met resource } \\
\text { objectives and only a change of the use in the Southwest } \\
\text { Pasture from late to early use is necessary. The assessment of } \\
\text { Standards for Rangeland Health showed the standards for } \\
\text { upland watershed function, ecological processes, and Special } \\
\text { Status species were achieved and riparian function and water } \\
\text { quality not present. The resource objectives need to be } \\
\text { rewritten to reflect resource conflicts and concerns identified } \\
\text { in the Three Rivers RMP. These concerns include erosion and } \\
\text { Special Status species. }\end{array}$ \\
\hline
\end{tabular}

The AMP was revised in 1998 to incorporate the recommendations from the allotment management evaluation and address conflicts and concerns identified in the Three Rivers RMP. The conflicts and concerns include water quality, erosion, big game habitat, big game forage allocations, riparian habitat, Special Status species, ACEC, range condition. The objectives to be met in the next 5 years are to cause an upward trend in the mid-seral stage mountain big sagebrush/Idaho fescue/Thurber needlegrass and Wyoming big sagebrush/bluebunch wheatgrass range sites in all of the pastures, while maintaining those sites in late-seral stage; increase the availability and production of upland forbs for sage grouse from May to mid-July; maintain at least 85 percent of the current stands of browse in healthy condition by ensuring a 1:1 ratio of seedling and young to dead and decadent bitterbrush plants; cause an upward trend in the fair condition riparian habitat in Little Pine Creek; and maintain the current biscuitroot gathering sites in their present condition in the Vanderveer and Highway Pastures. A grazing system has been designed which will meet these objectives. Key forage species and target utilization levels have been identified for each pasture.

A spring was developed in this allotment to provide clean water for livestock and wildlife and prevent trampling of the spring source and meadow around the spring. 


\section{FY 1997 and 1998 Accomplishments}

Allotment No. Allotment Name Category* Implementation Progress

5523

Tub Springs - $\quad$ I

Hart

*I = Improve; $\mathrm{M}=$ Maintain; $\mathrm{C}=$ Custodial

An allotment management evaluation was conducted in 1998 to analyze, interpret, and evaluate whether or not present management is meeting resource objectives. Results indicate that the system outlined in the AMP has not been followed for a few years, but that most objectives have been met. Stocking rate is slightly above carrying capacity, but sufficient nonuse has been taken to allow improvement. The assessment of Standards for Rangeland Health found the standards for riparian watershed function and water quality not present and the standards for upland watershed function, ecological processes, and Special Status species were achieved. The evaluation also recommended changing the Selective Management category for this allotment from an ' $\mathrm{M}$ ' to an ' $\mathrm{I}$ ' due to conflicts with the Eagle Picher diatomite mine and the potential for continued improvement in range conditions. The AMP was revised in 1998 to incorporate the recommendations from the allotment management evaluation and address the conflicts and concerns identified in the Three Rivers RMP. These conflicts and concerns include erosion and mineral development. The objective is to cause an upward trend in the low and mid-seral Wyoming big sagebrush/bluebunch wheatgrass, Wyoming big sagebrush/Sandberg bluegrass, Wyoming big sagebrush/Idaho fescue. A grazing system has been designed which will meet this objective. Key forage species and target utilization levels have been identified for each pasture.

An allotment management evaluation was conducted in 1998 to analyze, interpret, and evaluate whether or not present management is meeting resource objectives. Results indicate that the current management is meeting the objectives for uplands, erosion and sage grouse, but not for redband trout, water quality or riparian condition. Stocking rate appears to be slightly in excess of carrying capacity. The assessment of Standards for Rangeland Health found that the standards for upland watershed function and ecological processes were achieved, and the standards for riparian function, water quality, and Special Status species were not achieved. The evaluation recommends modifying the grazing system to better meet the resource objectives and rewriting the objectives to include the conflicts and concerns identified in the Three Rivers RMP. A small voluntary reduction in level of livestock use is also recommended.

A trough was replaced at a spring to replace a worn out one. 


\section{FY 1997 and 1998 Accomplishments}

\begin{tabular}{llll} 
Allotment No. & Allotment Name & Category* & Implementation Progress \\
\hline & $* \mathrm{I}=$ Improve $; \mathrm{M}=$ Maintain $; \mathrm{C}=$ Custodial
\end{tabular}

5528

Cooler

M

The AMP was revised in 1998 to incorporate recommendation from the allotment management evaluation and address conflicts and concerns identified in the Three Rivers RMP. The conflicts and concerns include erosion and Special Status species. The objectives are to cause an upward trend in the low and mid-seral Wyoming big sagebrush/bluebunch wheatgrass, Wyoming big sagebrush/Sandberg bluegrass, Wyoming big sagebrush/Idaho fescue, and keep a stable trend in the crested wheatgrass seeding; maintain a stable population of Trifolium leibergii within the allotment; increase the availability and production of upland forbs for sage grouse from April through mid-July in the allotment every year. A grazing system has been developed which will meet these objectives. Key forage species and target utilization levels have been identified for each pasture. The evaluation also recommended moving a portion of the permittee's grazing preference from the Upton Mountain Allotment into this allotment. A grazing decision will be prepared to implement this recommendation prior to increasing the stocking rate in the Cooler Allotment.

The AMP was revised in 1998 to incorporate recommendation from the allotment management evaluation and address conflicts and concerns identified in the Three Rivers RMP. These concerns include: water quality, big game habitat, wild horses, big game forage allocations, riparian habitat, Special Status species, and range condition. The objectives to be met in the next 5 years are to cause an upward trend in the midseral stage mountain big sagebrush/Idaho fescue/Thurber needlegrass and Wyoming big sagebrush/bluebunch wheatgrass range sites in all of the pastures, while maintaining those sites in late-seral stage; increase the availability and production of upland forbs for sage grouse from May to mid-July; maintain at least 85 percent of the current stands of browse in healthy condition by ensuring a 1:1 ratio of seedling and young to dead and decadent bitterbrush plants; and cause an upward trend in the fair and poor condition riparian habitat in Stinkingwater Creek and Warm Springs Creek. A grazing system has been developed which will meet these objectives. Key forage species and target utilization levels have been identified for each pasture.

In August 1998, a wildfire burned 444 acres in the Little Stinkingwater Pasture. Approximately 25 acres of highly erodible soils were seeded to shrubs and forbs and a protective fence will be constructed around the burned area to provide at least 2 years of rest from grazing to allow the vegetation to reestablish. Noxious weeds will be controlled if monitoring discovers weed invasion. 


\section{FY 1997 and 1998 Accomplishments}

Allotment No. Allotment Name Category* Implementation Progress

5535

Miller Canyon I

5536

Alder Creek

5571
Lamb Ranch
$* \mathrm{I}=$ Improve $; \mathrm{M}=$ Maintain $; \mathrm{C}=$ Custodial

An ongoing juniper control project cut 390 acres of western juniper in this allotment. The purpose of the project is to reduce juniper competition with grasses, forbs, shrubs, and in some areas, aspen trees. The cut trees have been left in place to provide beneficial micro-sites for desirable seedling establishment.

In August 1998, a wildfire burned 452 acres in the Coleman Creek Pasture. Approximately 25 acres of highly erodible soils were seeded to shrubs and forbs and a protective fence will be constructed around the burned area to provide at least 2 years of rest from grazing to allow the vegetation to reestablish. Noxious weeds will be controlled if monitoring discovers weed invasion.

An allotment management evaluation was conducted in 1997 to analyze, interpret, and evaluate whether or not present management is meeting resource objectives. Results indicate that the current management is meeting objectives for uplands and Special Status species. There is insufficient data to determine whether or not the objective for water quality is being met. There was insufficient data to calculate carrying capacity. The assessment of Standards for Rangeland Health shows the standards for upland function, ecological processes, and Special Status species have been achieved and it is unknown whether or not the riparian function and water quality standards have been achieved. An AMP was developed in 1998 which incorporates the recommendations from the allotment management evaluation and addresses the conflicts and concerns identified in the Three Rivers RMP. These conflicts and concerns include water quality, Special Status species, and rangeland condition. The objectives are to increase the availability and production of upland forbs for sage grouse from May to mid-July during the next 10 years, maintain all seral stages in current status to provide a diversity of habitat types and conditions and forage requirements during the next three grazing cycles, and cause an upward trend in the fair condition riparian habitat on 1.25 miles of Newell Creek. A grazing system has been developed which will meet these objectives. Key forage species and target utilization levels have been identified for the allotment. 


\section{FY 1997 and 1998 Accomplishments}

\begin{tabular}{llll} 
Allotment No. & Allotment Name & Category* & Implementation Progress \\
\hline & $* I=$ Improve; $M=$ Maintain; $C=$ Custodial
\end{tabular}

An allotment management evaluation was conducted in 1997 to analyze, interpret, and evaluate whether or not present management is meeting resource objectives. The results indicate that the grazing treatments identified in the AMP had not been followed and that most grazing use occurred during the growing season for the key forage grasses. In spite of this, poor distribution of livestock and overuse of the private land resulted in meeting resource objectives on the public land in the allotment. The evaluation recommended revising the AMP to incorporate a grazing system to meet resource objectives and rewriting the resource objectives to reflect the resource conflicts and concerns identified in the Three Rivers RMP. These include big game forage allocations and Special Status species.

Eight water holes were cleaned to increase their holding capacity which had decreased due to siltation.

A cattleguard was installed near the Silver Creek Bridge for livestock control. This project helps implement the AMP for this allotment.

Much of the private land in the allotment is being or has been fenced out of the allotment. Exchange of use agreements have been canceled where appropriate. Impacts of the new fences to the grazing system will be monitored and evaluated. The system will be modified if necessary.

The AMP was revised in 1998 to incorporate recommendations from the allotment management evaluation and address conflicts and concerns identified in the Three Rivers RMP. These concerns include big game habitat, playa habitat, Special Status species, and range condition. The objectives are to cause an upward trend in the mid-seral stage Wyoming big sagebrush/Thurber needlegrass/Idaho fescue range sites over the next 5 years, while maintaining those areas which are in late-seral stage; improve the availability and production of upland forbs for sage grouse from May to mid-July over the next 5 years; maintain the current stands of bitterbrush in healthy condition by maintaining a 1:1 ratio of seedling and young to dead and decadent plants over the next 5 years.

Wild horses in excess of Appropriate Management Levels (AMLs) were removed from this allotment in October 1998 to keep the herd area in a thriving natural ecological balance.

Wild horses in excess of AMLs were removed from this allotment in October 1998 to keep the herd area in a thriving natural ecological balance. 


\section{FY 1997 and 1998 Accomplishments}

\section{Allotment No. Allotment Name Category* Implementation Progress}

7036

Hayes

I

7062

7063
Capehart Lake I

Round Top Butte I
*I = Improve; $\mathrm{M}=$ Maintain $; \mathrm{C}=$ Custodial

An allotment management evaluation was conducted in 1998 to analyze, interpret, and evaluate whether or not present management is meeting resource objectives. The results indicate that the established grazing system had not been used consistently due to water shortages and nonuse. The carrying capacity exceeds the active preference, therefore, a portion of the suspended nonuse may be restored. The objectives for ecological condition and forage production for livestock and wildlife have been met and the objective for livestock distribution has been partially met in the North Pasture and not met in the South Pasture. The evaluation recommends modifications to the grazing system to better meet the resource objectives and rewriting the objectives to include the conflicts and concerns identified in the Three Rivers RMP.

Six and one-half miles of fence were constructed in this allotment. It will split the allotment into two pastures which will allow implementation of the grazing system outlined in the AMP.

The worn out trough at a well was replaced with a larger, bottomless trough. 


\section{ENVIRONMENTAL ASSESSMENT REGISTER}

The following are Environmental Assessments (EAs) which were scheduled but were not completed and new EAs recently initiated. The EAs for these projects are now completed or expected to be completed in FY99. A notice is published in the Burns Times-Herald when each new EA is available for review by the public and the date when the comment period ends.

If you would like to be involved in the planning process for any particular project or would simply like to receive a copy of an EA for review, note the EA register number and contact the District or the project's primary contact listed below. This should be done as early as possible to allow for full consideration of your input.

\begin{tabular}{|c|c|c|c|c|}
\hline $\begin{array}{l}\text { EA Register } \\
\text { Number }\end{array}$ & Project Name & Proposed Action & Location & $\begin{array}{l}\text { Critical } \\
\text { Element }\end{array}$ \\
\hline
\end{tabular}

* $020=$ Burns District, $025=$ Three Rivers Resource Area, $026=$ Andrews Resource Area

EA

OR-020*-90- Land Exchange 048

Primary

Contact:

Skip

Renchler
The proposed action is to exchange five solid waste disposal sites on 200 acres of public land currently leased to Harney County for 200 acres of County-owned land.

The purpose and need of the proposed action is to minimize the United States' potential liability under various hazardous and solid waste statutes; eliminate BLM's administration of the current leases; facilitate continued rural solid waste disposal by providing Harney County with long-term ownership of the disposal sites; and, dispose of isolated and unmanageable tracts of County-owned and BLMadministered land.

$\begin{array}{lll}\text { Various } & \text { None. } & \text { EA and } \\ \text { locations } & & \text { public } \\ \text { throughout } & & \text { comment } \\ \text { Harney } & & \text { period ended } \\ \text { County. } & & \text { in } 1990 .\end{array}$

Decision issued and exchange completed 03/98. 


\begin{tabular}{|c|c|c|c|c|c|}
\hline $\begin{array}{l}\text { EA Register } \\
\text { Number }\end{array}$ & Project Name & Proposed Action & Location & $\begin{array}{l}\text { Critical } \\
\text { Element }\end{array}$ & $\begin{array}{l}\text { Completion } \\
\text { Date/Deci- } \\
\text { sion/Action }\end{array}$ \\
\hline
\end{tabular}

\section{EA Cow Creek \\ OR-025*-92- Forest Health \\ $043 \quad$ Project}

Primary

Contact: Jon

Reponen
Primary

Contact: Jim

Buchanan
Stonehouse

AMP

059

\section{EA \\ OR-025-95- \\ 024}

Primary

Contact:

Rudy Hefter
The proposed action is to treat 225 acres in the Rattlesnake Forest Management area by the selective harvest of approximately $500 \mathrm{mbf}$ of timber, precommercial thinning of 55 acres, underburning 189 acres, removal of invading ponderosa pine from 13 acres of aspen, and fencing the aspen stands to enhance reproduction.

The purpose of this action is to improve forest health, to perpetuate and manage existing large diameter ponderosa pine trees, to salvage dead and dying trees, to improve stand vigor, lower risk of wildfire, and to return timber stands to their historic range of variability. This project was originally proposed in 1993, but was delayed. It is being reinitiated using the most current inventory data.

The proposed action is to implement a grazing system on the Stonehouse Allotment. This will be based on the evaluation.

The purpose of this action is to improve riparian and upland range condition and plant diversity on sagebrush and juniper dominated sites.

Malheur River/ The proposed action is to Bluebucket implement resource protecCreek Protec- tion for Special Management tion Project Areas.

The purpose of this action is to reduce livestock grazing impacts on Special Management Areas.
T. $21 \mathrm{~S} ., \quad$ Vegetative R.32-1/2E., health. Secs. 27, 28, 29 , and 33. 29 , and 33

\section{T. 30 and 31 \\ S., R. 34 and \\ $35 \mathrm{E}$., northeast side of Steens Mountain.}

Lower

\section{T. 18 S., R.} 34 E.,

Secs. 33 and 34, Bluebucket

Stonehouse WSA;

Riddle Creek and headwaters of Deep Creek.
Original EA completed Summer 1993; public comment period closed 08/25/93; EA rewritten Spring 1997; public comment period ended Spring 1997; Decision Record scheduled for Fall/Winter 1999. Allotment
evaluation is
planned for
FY99; EA
will be
completed
subsequently.

\author{
Creek and Middle EA expected \\ Fork of the FY99. \\ Malheur River. \\ Malheur River \\ Bluebucket Creek \\ WSA, recom- \\ mended Wild and \\ Scenic River, wa- \\ ter quality, and \\ bull trout habitat.
}




\begin{tabular}{|c|c|c|c|c|}
\hline $\begin{array}{l}\text { EA Register } \\
\text { Number }\end{array}$ & Project Name & Proposed Action & Location & $\begin{array}{l}\text { Critical } \\
\text { Element }\end{array}$ \\
\hline
\end{tabular}

\section{EA Texaco Basin \\ OR-025-95- Reservoir and \\ 029}

Primary

Contact: Jim

King

Primary

Contact:

Mark

Sherbourne

$\begin{array}{ll}\text { EA } & \text { Poison Creek } \\ \text { OR-025-96- } & \text { Reservoir } \\ 014 & \end{array}$

Primary

Contact:

Fred Taylor

EA Zeolite Mine
OR-025-96-
028

Primary

Contact:

Terri Geisler

The proposed action is to construct 6 miles of fence along the west side of the Warm Springs Road in the Texaco Basin Allotment.

The purpose of this action is to keep livestock away from Warm Springs Reservoir during the recreation season and allow better utilization of the crested wheatgrass seeding in the west half of the Reservoir Pasture.

The proposed action is to exchange approximately 1,945 acres of public land for 3,992 acres of private land around Mickey and Tule Springs and Stonehouse and Carlson Creeks.

The purpose of this action is to consolidate public and private lands into more manageable units and acquire important wildlife, riparian, and recreation values and important public access.

The proposed action is to construct a reservoir to hold approximately 140 acre-feet of water.

The purpose of this action is to create a fishery in the area to provide fishing opportunities to the public.

The proposed action is to develop a mine in a clay mineral deposit within the Eagle's Nest seeding by blasting, crushing, and hauling the rock.

The purpose is to mine zeolite minerals.
T. 22 and 23

S.,

R. 36 E.,

Secs. 22, 26,

$27,28,35$

and 2,11 .

Stonehouse and Carlson

Creeks;

Mickey and

Tule Springs; east slopes of

Steens

Mountain

and Alvord

Desert.

T. 18 S., R. 32 E., Sec.

17.

Riparian, recreation.

Recreation

EA comand riparian habitat.

pleted in FY97. Project in progress.
EA scheduled for completion in FY99.
T. 27 S., R. None.

30 E., Secs.

10 SE-1/4,

$11 \mathrm{SW} 1 / 4$, $15 \mathrm{NE} 1 / 4$, and 14

NW1/4.
EA completed 09/30/ 97. Work is being planned for completion in 1999.

EA was completed in FY97. Mining of zeolite started 12/97. 


\begin{tabular}{|c|c|c|c|c|}
\hline $\begin{array}{l}\text { EA Register } \\
\text { Number }\end{array}$ & Project Name & Proposed Action & Location & $\begin{array}{l}\text { Critical } \\
\text { Element }\end{array}$ \\
\hline
\end{tabular}

\section{EA Riddle Creek \\ OR-025-97- Ecosystem \\ 012 \\ Primary \\ The proposed action is to conduct prescribed burns on approximately 10,000 acres over a 5 to 10 -year period in mountain big sagebrush sites that have been invaded by juniper.}

Contact: Bill

Andersen

\section{EA Gouldin \\ OR-025-97- Pipeline \\ 013}

Primary

Contact: Bill

Andersen

$\begin{array}{ll}\text { EA } & \text { Stone Gap } \\ \text { OR-025-97- } & \text { Fence } \\ 014 & \end{array}$

Primary

Contact:

Bill Andersen
The purpose of this action is to maintain ecological function of these sites.

The proposed action is to install a pipeline and trough.

The purpose of this action is to improve livestock distribution through additional water.

The proposed action is to construct one-quarter mile fence to keep wild horses off private land.

Primary

Contact:

Jim King

T. 29 and 30

S., R. 34 and

Kiger

35 E., Riddle

Mountain,

Smyth

Creek,

Happy

Valley, and

Burnt Flat

Allotments.

T. 23 and 24 S., R. 30 E., Secs. 31 and 6.

T. 30 S., R. 35 E., Sec. 34.
Mustang

ACEC.

None.

Stonehouse

WSA and

Kiger

Mustang

ACEC.

$\begin{array}{lll}\text { T. 29 S., R. } & \text { Kiger } & \text { EA was } \\ \text { 34 E., Secs. } & \text { Mustang } & \text { completed in } \\ \text { 8, } 9,16,21, & \text { ACEC. } & \text { Fall 1997. } \\ \text { 22, 23, 27, } & & \text { Decision } \\ \text { 29, 30, 32, } & & \text { signed 12/07/ } \\ \text { 33; T. 30 S., } & & 97 \text { to do } \\ \text { R. 34 E., } & & \text { project. } \\ \text { Sec. 19. } & & \text { Expect to do } \\ & & \text { project } 1999 \\ & & 2000 .\end{array}$

T. 24 S., R. None. 34 E., Sec. 14.
The proposed action is to install 5 miles of fence.

The purpose of this action is to protect 6 miles of riparian habitat and will facilitate management of livestock grazing.
Tin Can Fire Seeding

$\begin{array}{ll}\text { EA } & \text { Tin Can Fire } \\ \text { OR-025-97- } & \text { Seeding } \\ 022 & \end{array}$

Primary

Contact: Fred Taylor
The proposed action is to seed 100 acres with bitterbrush and native bluebunch wheatgrass.

The purpose of this action is to establish native vegetation on a juniper cutting area subsequently burned.
EA was completed in Winter 1998. 2,200 acres completed in 1998.

EA was completed in Fall 1997. The proposal was dropped.

EA was completed in Fall 1997 and project completed Summer 1998.
EA com- pleted in Summer 1997.
Decision was signed 09/23/ 97. Project completed. 


\begin{tabular}{|c|c|c|c|c|c|}
\hline $\begin{array}{l}\text { EEA Register } \\
\text { Number }\end{array}$ & Project Name & Proposed Action & Location & $\begin{array}{l}\text { Critical } \\
\text { Element }\end{array}$ & $\begin{array}{l}\text { Completion } \\
\text { Date/Deci- } \\
\text { sion/Action }\end{array}$ \\
\hline
\end{tabular}

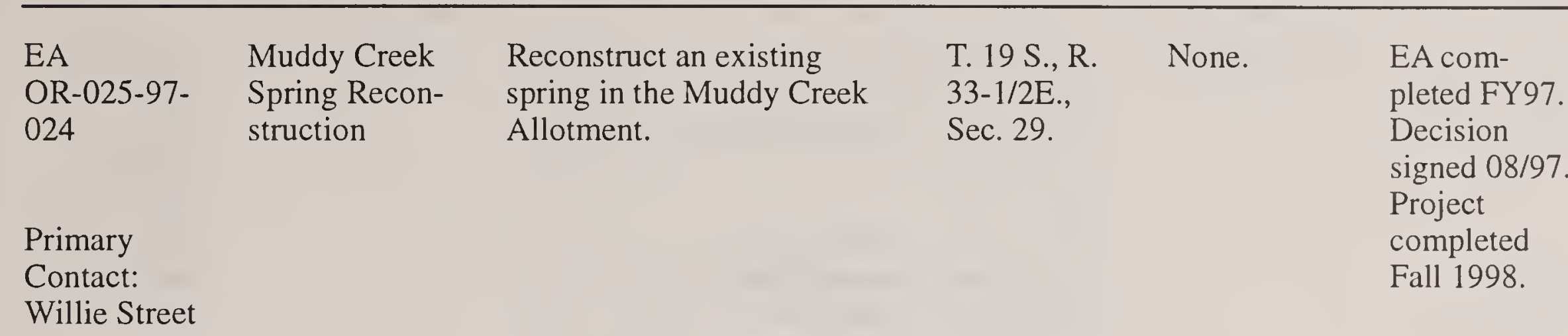

$\begin{array}{ll}\text { EA } & \text { Cottonwood } \\ \text { OR-026-97- } & \text { Creek Fire } \\ \text { 031 } & \text { Rehabilitation } \\ & \text { Plan }\end{array}$

Primary

Contact:

Fred

McDonald
EA
OR-025-98-
003
Primary
Contact:
Rudy Hefter

\section{EA}

OR-025-98005

Primary

Contact:

Rudy Hefter
Newell Creek The proposed action is to Fence construct 2.5 miles of fence and removal of 2 miles of fence.

The purpose of this project is to facilitate the recovery of riparian areas in the Silvies Allotment.

Integrated Weed The proposed action was to Management develop an integrated Weed Management Plan for the Burns District including control methods, and priority areas.

The purpose of this proposal is to implement a long-term weed management program outlining goals for prevention and detection, education, inventory, planning, control, monitoring, and evaluations.
T. 33 S., R. WSA.

34 E., east Recreation

side of

Steens

Mountain.

T. 18. S., R. 32 S., Silvies Valley.

Burns

District.

$$
\begin{aligned}
& \text { WSAs, } \\
& \text { RNAs., } \\
& \text { ACECs, } \\
& \text { Special } \\
& \text { Status plants } \\
& \text { and animals. }
\end{aligned}
$$

EA completed 09/97. Decision signed 11/98. Project completed 01/98.

EA completed 10/97. Project was completed Fall 1998. 


\begin{tabular}{|c|c|c|c|c|}
\hline $\begin{array}{l}\text { EA Register } \\
\text { Number }\end{array}$ & Project Name & Proposed Action & Location & $\begin{array}{l}\text { Critical } \\
\text { Element }\end{array}$ \\
\hline
\end{tabular}

EA
OR-026-98-
006

Primary

Contact:

Rick Hall

$\begin{array}{ll}\text { EA } & \text { East Creek } \\ \text { OR-026-98- } & \text { Exclosure } \\ 007 & \end{array}$

Primary

Contact:

Carolyn

Chad

$\begin{array}{ll}\text { EA } & \text { Bossuot Cabin } \\ \text { OR-025-98- } & \text { Life Estate } \\ 010 & \text { Lease }\end{array}$

Primary

Contact:

Skip

Renchler

$\begin{array}{ll}\text { EA } & \text { Dry Pine } \\ \text { OR-025-98- } & \text { Precommercial } \\ 014 & \text { Thinning and } \\ & \text { Aspen Rehabili- } \\ & \text { tation }\end{array}$

Primary

Contact:

Rudy Hefter
The proposed action is to construct .75-mile of fence along the south side of the county road.

The purpose of this action is to facilitate livestock management in a small area adjacent to private land.

The proposed action is to construct an exclosure (.8mile fence).

The purpose of this action is to protect the riparian area.
T. 39 S., R. 35 E., Trout Creek Lane.

Pueblo Mountains.
None.

EA completed Fall 1997.

Decision signed 02/19/ 98. Project completed.
T. 20 S., R. None. 29 E., Sec. 34.

The purpose of this action is to authorize an existing cabin built inadvertently on public land many years ago.
The proposed action is to implement forest management activities in various areas; including precommercial thinning on 415 acres, most conifers cut on 3-20-acre aspen sites.

The purpose of the action is to reduce overstocked ponderosa pine stands to improve forest health, reduce risk of "stand replacement" fires, restore degraded aspen stands and protect areas of high value from catastrophic wildfire, insects, and disease.
Pine Creek, None. Rattlesnake Creek, Loco Canyon, and Dry Mountain.
EA completed 01/12/ 98; Decision signed 04/01/ 98 , lease issue.
Decision signed 05/06/ 98. Project planned for FY99. 


\begin{tabular}{|c|c|c|c|c|c|}
\hline $\begin{array}{l}\text { EA Register } \\
\text { Number }\end{array}$ & Project Name & Proposed Action & Location & $\begin{array}{l}\text { Critical } \\
\text { Element }\end{array}$ & $\begin{array}{l}\text { Completion } \\
\text { Date/Deci- } \\
\text { sion/Action }\end{array}$ \\
\hline
\end{tabular}

\begin{tabular}{|c|c|c|}
\hline $\begin{array}{l}\text { EA } \\
\text { OR-025-98- } \\
016\end{array}$ & $\begin{array}{l}\text { Dry Mountain } \\
\text { Fences. }\end{array}$ & $\begin{array}{l}\text { The proposed action is to } \\
\text { construct two fences }(5.25 \\
\text { miles) for improved livestock } \\
\text { management. }\end{array}$ \\
\hline $\begin{array}{l}\text { Primary } \\
\text { Contact: } \\
\text { Nora Taylor }\end{array}$ & & $\begin{array}{l}\text { The purpose of the proposal } \\
\text { is to exclude livestock from a } \\
\text { parcel of land BLM recently } \\
\text { acquired through a land } \\
\text { exchange and to close an } \\
\text { allotment boundary which } \\
\text { will improve livestock } \\
\text { control. }\end{array}$ \\
\hline $\begin{array}{l}\text { EA } \\
\text { OR-026-98- } \\
023\end{array}$ & $\begin{array}{l}\text { Sand Hollow } \\
\text { Fence and } \\
\text { Trough }\end{array}$ & $\begin{array}{l}\text { The proposed action is to } \\
\text { construct } .75 \text {-mile of fence } \\
\text { and install a water trough. }\end{array}$ \\
\hline $\begin{array}{l}\text { Primary } \\
\text { Contact: } \\
\text { Dave Ward }\end{array}$ & & $\begin{array}{l}\text { The purpose of this action is } \\
\text { to facilitate the management } \\
\text { of livestock in the Reichen's } \\
\text { Corner Allotment. }\end{array}$ \\
\hline
\end{tabular}
EA South Steens
OR-026-98- Herd Manage- 027

Contact:

Jim

The proposed action was to remove approximately 200 the HMA.

The purpose of the proposed action was to achieve the AML and to restore and maintain a thriving ecological
T. 22 S., R. None. 27 E., Sec.

19.

T. 21 S., R.

$26 \mathrm{E}$., Sec.

$10,11,12$,

13., near Dry

Mountain.
Primary

Buchanan

T. 32 S., R. None.

30 E., Sec.

1., Reichen's

Corner

Allotment. horses from and adjacent to balance; protecting and enhancing WSAs, Wild and Scenic River areas, water quality, and habitat for Catlow Valley redband trout.

$\begin{array}{ll}\text { EA } & \text { Chicken Spring } \\ \text { OR-025-98- } & \text { Fire Rehabilita- } \\ 031 & \text { tion }\end{array}$

Primary

Contact:

Bill

Andersen
Southwest

Steens

Mountain.

T. 23 S., R. $35 \mathrm{E}$., Sec. 26, 35 .
The proposed action is to rehabilitate a 900 -acre wildfire that burned 08/98. This will be done by drilling shrubs and forbs on approximately 50 acres and constructing 3.5 miles of fence.

The purpose of the action is to minimize water erosion in high potential sites and restore wildlife habitat. The fence will exclude livestock until the site is restored.

WSAs, Wild
and Scenic
River,
sensitive
fish.

Decision was issued "Full Force and Effect" 09/ 01/98.

Gathering was completed Fall 1998.

\section{signed 11/24/ 98. Project planned for FY99.}

EA expected FY99. 


\begin{tabular}{|c|c|c|c|c|}
\hline $\begin{array}{l}\text { EA Register } \\
\text { Number }\end{array}$ & Project Name & Proposed Action & Location & $\begin{array}{l}\text { Critical } \\
\text { Element }\end{array}$ \\
\hline
\end{tabular}

\section{EA \\ OR-026-98- 032 \\ Skull Creek \\ Complex Fire \\ Rehabilitation}

Primary

Contact:

Jim

Buchanan

EA

OR-026-98-

033

Primary

Contact:

Gina

Lampman
The proposed action is to drill and aerial seed and fence portions (830 acres) of the burned area on public land (5,500 acres public and 15,000 acres private). The private landowner is also reseeding and fencing. Native plant species will be utilized where possible and temporary fences used to protect the area.

The purpose of the action is to revegetate approximately 1,350 acres of the burned area to prevent a dominant cover of annual cheatgrass.

Lauserica Fence

The proposed action is to construct approximately 9.1 miles of fence $(7.7$ miles on public, 1.25 miles on private land) to separate the Steens Pasture from the Home Creek Pasture; and to construct approximately 1 -mile of fence on public land to separate Home Creek Pasture from Stephens Pasture. Existing nonfunctional fence would be removed.

The purpose of the proposed activity is to provide additional livestock control enabling more effective management of livestock grazing. This will facilitate activities necessary to achieve the conservation goals of the Conservation Agreement, rangeland improvement goals of the South Steens AMP, and water quality goals of the South Steens WQMP.

$\begin{array}{ll}\text { T. } 36 \mathrm{~W} ., \mathrm{R} . & \text { Catlow } \\ 31 \text { and } 32 \mathrm{E} . & \text { Conservation } \\ & \text { Agreement } \\ & \text { Area, } \\ & \text { sensitive fish } \\ & \text { species, } \\ & \text { Catlow tui } \\ & \text { chub, and } \\ & \text { redband } \\ & \text { trout, WSA. }\end{array}$

EA completed and Decision signed 09/28/ 98. Project will be completed Spring 1999.
T. 34 S., R. Home Creek 31 and 32 E. WSA, South Fork Donner und Blitzen WSA, Special
Status fish.

EA completed 10/30/ 98 and proposed Decision signed 01/11/ 99. Project planned for FY99 completion. 


\begin{tabular}{|c|c|c|c|c|c|}
\hline $\begin{array}{l}\text { EA Register } \\
\text { Number }\end{array}$ & Project Name & Proposed Action & Location & $\begin{array}{l}\text { Critical } \\
\text { Element }\end{array}$ & $\begin{array}{l}\text { Completion } \\
\text { Date/Deci- } \\
\text { sion/Action }\end{array}$ \\
\hline
\end{tabular}

$\begin{array}{ll}\text { EA } & \text { Raz Lewis Flat } \\ \text { OR-026-98- } & \text { Fire Rehabilita- } \\ 034 & \text { tion }\end{array}$

Primary

Contact:

Cam Swisher
The proposed action is to rehabilitate a 2,346-acre wildfire area burned July 1998. This will be done by reseeding approximately 650 acres with a mixture of native plants and constructing approximately 3.5 miles of temporary fence.

The purpose of this action is to reestablish native perennial vegetation in an area with an influx of cheagtgrass and a resulting high fire frequency.

$\begin{array}{ll}\text { EA } & \text { Dry Creek Fire } \\ \text { OR-026-98- } & \text { Rehabilitation } \\ 036 & \end{array}$

Primary

Contact:

Dave

Blackstun

The proposed action is to rehabilitate and construct 5 miles of temporary fence to protect approximately 3,600 acres of wildfire burned in two areas.

The purpose of this action is to exclude livestock in these

Primary

Contact:

Jim

Buchanan

$\begin{array}{ll}\text { EA } & \text { East Fork/Head } \\ \text { OR-026-99- } & \text { waters Fence } \\ 008 & \text { Realignment }\end{array}$

Primary

Contact:

Carolyn

Chad

T. 37 S., R.

Basque Hills $32 \mathrm{E}$. areas to allow natural recovery of the vegetation.

The proposed action is to rehabilitate a 1,750 -acre wildfire by reseeding the burned area and constructing 6.5 miles of fence.

The purpose of this action is to reestablish perennial vegetation in an area with an influx of annual cheatgrass and a resulting high fire frequency.

The proposed action is to remove fence and realign the pasture division fence in Trout Creek Allotment.

The purpose is to eliminate the need for an existing uneffective exclosure along the east fork of Trout Creek, and remove the existing pasture fence from a snow field.
T. 24 S., and

T. 35 S.,

R. 32-1/2 E.,

Sec. 3, 4, 33, and 34 .
WSA,

Rincon

WSA.
South Fork

Donner und

Blitzen

WSA, South

Steens HMA.
T. 41 S., R. WSA.

$38 \mathrm{E}$., various sections.
Decision

signed 09/28/

98. Project

completed 11/98.

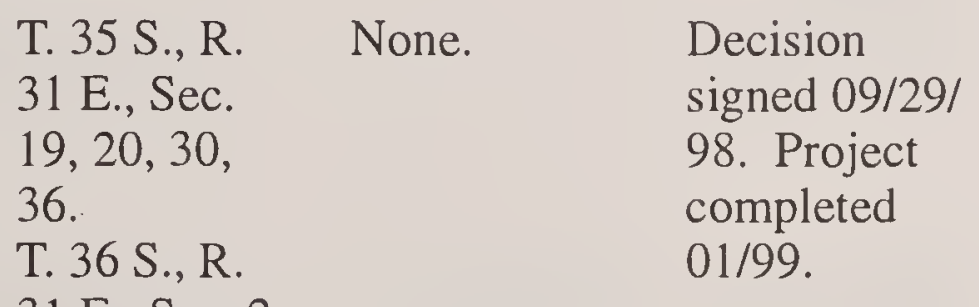

31 E., Sec. 2.
Decision signed 09/28/ 98. Project will be completed in FY99.
EA expected by $06 / 99$. 


\begin{tabular}{|c|c|c|c|c|c|}
\hline $\begin{array}{l}\text { EA Register } \\
\text { Number }\end{array}$ & Project Name & Proposed Action & Location & $\begin{array}{l}\text { Critical } \\
\text { Element }\end{array}$ & $\begin{array}{l}\text { Completion } \\
\text { Date/Deci- } \\
\text { sion/Action }\end{array}$ \\
\hline
\end{tabular}

$\begin{array}{lll}\text { EA } & \text { Tum Tum } & \text { The proposed action is to } \\ \text { OR-026-99- } & \begin{array}{l}\text { Allotment } \\ \text { Evaluation and } \\ \text { evaluate livestock carrying } \\ \text { capacity of the Tum Tum }\end{array} \\ & \text { AUM Increase } & \text { Allotment. }\end{array}$

Primary

Contact:

Rick Hall

$\begin{array}{ll}\text { EA } & \text { Abandoned } \\ \text { OR-026-99- } & \text { Mined Land } \\ 010 & \text { Remediation }\end{array}$

Primary

Contact:

Thresa

Geisler

$\begin{array}{ll}\text { EA } & \text { Exclosure } \\ \text { OR-025-99- } & \text { Fences } \\ 011 & \end{array}$

Primary

Contact:

Nora Taylor

$\begin{array}{ll}\text { EA } & \text { Kiger Horse } \\ \text { OR-025-99- } & \text { Gather } \\ 013 & \end{array}$

Primary

Contact:

Rudy Hefter

The purpose of the action is

to license available forage

consistent with meeting

management objectives.

The proposed action is to place grates, backfill or fence shafts and adits and remove or leave nearby mining remains.

The purpose of this action is hazards and hazardous materials.

The proposed action is to construct exclosure fences around unalloted areas having Special Status plant populations.

The purpose is to exclude livestock from these areas and provide

The proposed action is to gather wild horses in the Smyth/Kiger HMA down to the AML identified in the land use plan.

The purpose of the action is to ensure a thriving, natural
T. 40 S., R. Special

35 E., Sec. 5, Status plant

EA expected

$6,7,8,17, \quad$ and fish

18,19 , and species.

20, 15 miles

Fields.

Several

WSAs. to remove the potential safety

locations east side of Steens, Denio Basin, and Catlow Valley. ecological balance between wild horse populations and other values, and to perpetuate the special unique characteristics of the herd.
Various locations in Three Rivers Resource Area.
Special EA expected Status plants. by 07/99.
EA expected by $06 / 99$.

\section{North Steens. Kiger Mustang \\ EA expected by $06 / 99$.} ACEC. 


\begin{tabular}{|c|c|c|c|c|c|}
\hline $\begin{array}{l}\text { EA Register } \\
\text { Number }\end{array}$ & Project Name & Proposed Action & Location & $\begin{array}{l}\text { Critical } \\
\text { Element }\end{array}$ & $\begin{array}{l}\text { Completion } \\
\text { Date/Deci- } \\
\text { sion/Action }\end{array}$ \\
\hline
\end{tabular}

$\begin{array}{ll}\text { EA } & \text { Pack Trail } \\ \text { OR-026-99- } & \text { Fence Exten- } \\ 014 & \text { sion }(6010)\end{array}$

Primary

Contact:

Manuel

Berain

$\begin{array}{ll}\text { EA } & \text { McCoy Creek } \\ \text { OR-026-99- } & \text { Protection } \\ 015 & \text { Fence }\end{array}$

Primary

Contact:

Manuel

Berain

Primary

Contact:

Jim King

$\begin{array}{ll}\text { EA } & \text { Stinkingwater } \\ \text { OR-025-99- } & \text { Allotment } \\ 017 & \text { Water Develop- } \\ & \text { ments }\end{array}$

Primary

Contact:

Jim King

$\begin{array}{ll}\text { EA } & \text { Tudor Lake } \\ \text { OR-026-99- } & \text { Fence } \\ 018 & \end{array}$

Primary

Contact:

Dave Ward

The proposed action is to construct approximately .5mile of fence along a portion of McCoy Creek.

The purpose of the action is to improve riparian area management along approximately 2 miles of the creek.

The proposed action is to construct approximately 1.1 miles of fence along the allotment boundary.

The purpose of the project is to prevent cattle movement between the two allotments, and improve management along approximately 10 miles of McCoy Creek and its tributaries.

The proposed action is to construct 6 miles of fence for a separate pasture.

The purpose of this action is to protect and enhance riparian areas.

The proposed action is to develop three springs and one waterhole.

The purpose of this action is to get better livestock distribution.

The proposed project is to construct .5-mile of fence across public land.

The purpose of this action is to improve livestock management. Allotment.
T. 31 S., R.

33 E., Sec.

20., McCoy

Creek.

\section{T. 32 S., R. High Steens EA is 33 E., Sec. WSA. expected 03/ 17 and 20., 99.}

EA is expected $03 /$ 99.

McCoy

Creek.

T. 22 S., R. Biscuitroot $34 \mathrm{E}$., Cultural Stinkingwater ACEC.

Stinkingwater

Biscuitroot Allotment.

Cultural ACEC.

EA expected 03/99.

EA expected 03/99.

T. 31 S., R. None.

EA expected 35 E., Sec. 2.
02/99. 


\begin{tabular}{|c|c|c|c|c|c|}
\hline $\begin{array}{l}\text { EA Register } \\
\text { Number }\end{array}$ & Project Name & Proposed Action & Location & $\begin{array}{l}\text { Critical } \\
\text { Element }\end{array}$ & $\begin{array}{l}\text { Completion } \\
\text { Date/Deci- } \\
\text { sion/Action }\end{array}$ \\
\hline
\end{tabular}

$\begin{array}{ll}\text { EA } & \text { East Ridge } \\ \text { OR-026-99- } & \text { Prescribed } \\ 019 & \text { Burns and } \\ & \text { Juniper Cutting }\end{array}$

Primary

Contact:

Jim

Buchanan
To cut juniper in preparation to restore the natural function of fire within aspen stands and adjacent to riparian zone within Kiger Gorge. Approximately 2,000 acres of public land would have fire reintroduction within a 5-10 year period.

The purpose of this action is to restore species' diversity to remnant aspen stands currently dominated by western juniper and to allow deciduous woody species to expand in community dominance along stream segments where juniper is filling the niche of these species. Restoration of ecological function.
T. 31 S., R. 33 and 34 E., Secs. 3, 6, 7, $11,18,19$, and 30 .
Kiger Creek. EA is scheduled for completion during FY99.


BLM Library

Denver Federal -521

Bldg. 50, OC-527

P.D. Box 250472025 
UNITED STATES

DEPARTMENT OF THE INTERIOR

BUREAU OF LAND MANAGEMENT

BURNS DISTRICT OFFICE

HC 74-12533 Hwy 20 West

Hines, Oregon 97738

OFFICIAL BUSINESS

PENALTY FOR PRIVATE USE, $\$ 300$
FIRST CLASS MAIL

POSTAGE \& FEES PAID

Bureau of Land Management Permit No. G-76

DISTRICT MANAGER

USDI BLM COOS BAY DI

1300 AIRPORT LN

NORTH BEND OR 97459

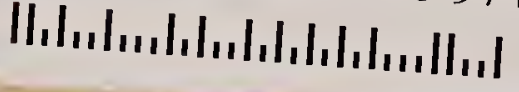

